\title{
Standing at the Intersection of Race and Class in Music Education
}

\author{
Vincent C. Bates \\ Weber State University (USA)
}

The main purpose of this essay is to critically analyze why social class receives relatively little attention in American social justice scholarship in music education. An associated aim is to make a case for more extensive considerations of class, including a much stronger intersectional alliance between critical class and antiracist scholarship. In particular, an intersectional approach to class and race is shown to have explanatory and political potential in music education, particularly in the controversy surrounding Michael Butera's resignation as NAfME Executive Director. The article concludes with a call for solidarity among all who strive for social justice in music education.

Keywords: social class, socioeconomic status, race, antiracism, classism

I

n 2018, fifty years after the original Poor People's Campaign and the assassination of its primary organizer and visionary, Martin Luther King Jr., a modern-day Poor People's Campaign-A National Call for Moral Revival-has emerged, led by the Reverend Dr. William J. Barber II to protest growing inequality and bring to light the plight of people living in poverty. This social movement, like the original one, responds with marches and civil disobedience relative to three interlocking injustices-systemic racism, poverty, and the war economy and militarism - with the addition of a fourth injustice and more recent threat: ecological devastation (Institute for Policy Studies 2018). As part of this new campaign and of special interest to music educators, activists have revived some of the civil rights songs from the past-songs like Everybody's Got a Right to Live! with the addition of modern hip hop conventions (see and hear https://www.youtube.com/watch ?v=7G4D8bdkqEo). 
[Sung]

Everybody's got a right to live.

Everybody's got a right to live.

And before this campaign fails

We'll all go down to jail.

Everybody's got a right to live.

[Spoken in call and response]

Everybody's got a right to live (to live!)

Everybody's got a right to dream (to dream!)

Everybody's got a right to love (to love!)

Everybody's got a right to learn (to learn!)

Everybody's got a right to ... [repeat the chorus]

The Poor People's Campaign calls upon people everywhere to remember their deepest ideals-human rights to life, love, learning, and dreams-because many people "appear to have forgotten their own values and become blind to the needs of other human beings, even those they may still hold in their hearts" (Institute for Policy Studies 2018, 3). This work-to change hearts, minds, and actions, especially when combined with critical thought and social research-can have significant impacts. Sadly though, history indicates that only a few of the most powerful will be amenable to a change of heart. Avarice is too firmly entrenched (see Giridharadas 2018). Plus, much of the problem lies in often less obvious institutional injustices rather than in minds and hearts alone (Sullivan 2014). So, along with other social movements throughout the world, the modern Poor People's Campaign is a call for social majorities to rise up in popular solidarity and fight the destructive power of global neoliberal capitalism and White supremacy.

Formal music education, like other social institutions, reproduces and perpetuates inequality and injustice (Wright 2015, Bates 2018a). When approached critically, however, music education can be influential in addressing an array of social and environmental crises (see Shevock and Bates 2019). In response to these realities and potentialities, it appears that a growing number of music educators and academics are devoting their labor to addressing social and environmental (Shevock 2018) injustices in and through music education, attempting to change the hearts or practices of fellow music educators and policy makers-to stand up in the face of oppression and exploitation. Lately, within this discourse, antiracism has become a key topic of study. Of special note, according to Google Scholar metrics, the most cited articles in Action, Criticism, and Theory for Music Education are two groundbreaking and insightful essays by Deborah Bradley: "The Sounds of

Bates, Vincent C. 2019. Standing at the intersection of race and class in music education. Action, Criticism, and Theory for Music Education 18 (1): 117-6o. doi:10.22176/act18.1.117 
Silence: Talking Race in Music Education" (2007) and "Music Education, Multiculturalism and Anti-Racism: Can We Talk?” (2006). Bradley has continued this important work, recently with a chapter (Bradley 2017) in College Music Curricula for a New Century, edited by Robin Moore (2017). In addition, Vicki Lind and Connie McKoy have contributed a practical textbook, Culturally Responsive Teaching in Music Education (2016), wherein they focus on race, ethnicity, and culture, along with gender. Race and racism are also primary themes in Brent Talbot's edited collection, Marginalized Voices in Music Education (2018), including four powerful chapters (out of 10) authored or co-authored by Black music educators-Joyce McCall (2018), Deejay Robinson (Robinson and Hendricks 2018), Darrin Thornton (2018), and "Dorothy" (Hendricks and Dorothy 2018), plus a chapter on Mariachi education, four chapters on gender and sexuality, and one chapter on visual impairment. The Handbook of Social Justice (2015) edited by Cathy Benedict, Patrick Schmidt, Gary Spruce, and Paul Woodford, devotes multiple chapters to race and ethnicity (Kelly-McHale and Abril 2015, Marsh 2015, Bradley 2015, Roberts and Campbell 2015, Ladson-Billings 2015, Gaztambide-Fernández and Rose 2015, Woodward 2015, Soto 2015). In 2016, Lisa DeLorenzo edited Giving Voice to Democracy in Music Education: Diversity and Social Justice, which included her own well-researched article on urban music education and race. Finally, over the past five years, Juliet Hess has produced a series of incisive, critical articles addressing race in music education (e.g. Hess 2013, 2014, 2015a, 2015b, 2016, 2018a, 2018b). This clear antiracist trend is welcome, encouraging, and long overdue. Antiracism is vital to action for change in music education, a field that continues to be shaped by White privilege and cultural elitism.

Considerably less social justice work has focused on social class in music education. The Handbook of Social Justice in Music Education (2015) can serve as an illustration. The editors acknowledge class in their preface: "Social justice ... is a term that is often employed in the educational literature as a catch-all expression and a political call to action for those seeking the amelioration of any number of social problems relating to, for example, class, ethnicity, gender, sexuality, disability, and cultural identity" (Kindle loc. 174, emphasis added). And class is mentioned throughout the handbook within the context of other topics, most often as one demographic element in a list (e.g. race, gender, ability, class, etc.), as in the preface. There are also a number of passing references to White middle-class people and their privilege, as well as other contexts in which class is discussed in conjunction with specific Black or Brown racial groups. Two chapters include more

Bates, Vincent C. 2019. Standing at the intersection of race and class in music education. Action, Criticism, and Theory for Music Education 18 (1): 117-6o. doi:10.22176/act18.1.117 
extensive discussions of class: Ruth Wright (2015) addresses class as an element in social reproduction, and Eric Shieh (2015) includes class in his review of El Sistema. However, while entire chapters are devoted to race, ethnicity, sexuality, gender, and ability, no chapters specifically or systematically treat class. In her chapter on race and racism, Bradley (2015) mentions class as she cautions against discourses that elide race: "Another difficulty related to academic engagements with ideas of race results from a common slippage-the ease with which discussions of race turn to issues of gender and class-both of which may be part of an issue better identified as racism (depending on the context), but for a variety of reasons subsume race discursively" (192). This is certainly a valid concern in many contexts, but in the Handbook of Social Justice in Music Education, at least, it is social class that appears to have been subsumed.

Critical considerations of social class are similarly sparse within the rest of the contemporary music education literature, particularly in North America (northern European and Australian scholars in music education seem more attuned to social class, e.g. Hall 2018, multiple chapters in Burnard 2016, and Dyndahl et al. 2014). Also on an international level, in 2016 Geoffrey Baker guest edited a special issue of ACT on El Sistema that included four articles in which social class figured prominently (Bates 2016a, Baker 2016, Logan 2016, Bull 2016). Otherwise, in the North American literature on music education, one can find a series of articles seeking a causal link between music education and school achievement for students from low-income families (Fitzpatrick 2006, Tierney et al. 2013, Doyle 2014, Slater et al. 2015), a couple of studies linking socioeconomic status (SES) with music festival ratings (Bergee 2006, Speer 2012), and a few articles that point out the underrepresentation of poor and "minority" students in school music (Albert 2006, Elpus and Abril 2011, Antmann 2015). A handful of essays address class, poverty, or socioeconomic status in music education from a social justice perspective (Bates 2011, 2012, 2017, 2018b; Hoffman 2013; McAnally 2013). Finally, Joseph Abramo (2017) recently contributed an innovative essay to the Philosophy of Music Education Review in which he applies "Marx's theories of labor, value, and phantasmagoria to suggest a capitalist logic that structures [school ensemble] competitions" (150). Articles such as these contribute much to the literature, but they constitute a very small fraction of what has been written about social justice in music education over the past dozen years or so. All in all, music education academics tend to elide social class concerns. Furthermore, this imbalance appears to be somewhat 
unique to class; intersections with gender, sexuality, and dis/ability are accorded relatively more attention.

A primary aim in this paper is to explore this discrepancy. Why does social class appear to occupy a lesser position in American social justice scholarship, especially given the class roots (both Marxian and Christian) of critical social theory and critical pedagogy. An associated aim is to make a case for more extensive considerations of class, including a much stronger intersectional alliance between critical class and antiracist scholarship in music education. To these ends, I first discuss advantages of and justifications for approaching class and race critically and intersectionally. Then I give some historical context for this intersectionality, primarily from a North American perspective. Next, I analyze how this intersectional approach to class and race has explanatory and political potential in music education, specifically surrounding the controversy leading to and the aftermath of Michael Butera's resignation as Executive Director of the National Association for Music Education (NAfME). Finally, I return to the Poor People's Campaign, along with related scholarship and popular media, to make a case and extend a call for inclusivity and solidarity among all who strive for social justice in music education.

\section{Intersectionality}

Intersectionality is reflected in the previously mentioned Poor People's Campaign to address disparate oppressive and exploitive forces all at once and in solidarity. The following statement from the Poor People's Campaign speaks to this necessity within the United States:

These issues demand that we dispel the notion that systemic racism, poverty, ecological devastation and the war economy hurt only a small segment of our society. More than 40,600,000 Americans subsist below the poverty line [and] there are close to 140 million people dealing with some combination of these crises every day. Nearly half of our population cannot afford a $\$ 400$ emergency, which presents a structural crisis of national proportion that ties poverty to things like healthcare and housing. The devastation cuts across race, gender, age, and geography. It has carved a dangerous and deepening moral chasm in America and inflicts a tragic loss of purpose, even among the affluent. (Institute for Policy Studies 2018)

Thirty years ago, when Kimberlé Crenshaw (1989) introduced the term intersectionality to describe the simultaneous experience of multiple faces of oppression, she stood on the shoulders of other Black feminists who had already theorized “'interlocking oppressions,' 'simultaneous oppressions,' 'double jeopardy,' 'triple

Bates, Vincent C. 2019. Standing at the intersection of race and class in music education. Action, Criticism, and Theory for Music Education 18 (1): 117-6o. doi:10.22176/act18.1.117 
jeopardy,' or any number of similar descriptive terms" (Smith 2015, Kindle loc. 3027-29). They applied intersectional analyses to bring attention to the needs of a specific demographic, drawing from Marxist theory to critique the dominance within women's movements of White middle- and upper-class women's perspectives (Cassell 2017). As Sharon Smith (2015) explains, class was central to the work of Black feminists as they expanded Marxist theories of class exploitation to reflect on the confluence of race and gender in Black female, working class experience. For example, Francis M. Beal, in her 1969 Black Women's Manifesto, wrote: “The system of capitalism (and its after birth ... racism) under which we live, has attempted by many devious means to destroy the humanity of all people, and particularly the humanity of Black people" (para. 1). More recently, Patricia Hill Collins (1995) explained: "While a Black woman's standpoint and its accompanying epistemology stem from Black women's consciousness of race and gender oppression, they are not simply the result of combining Afrocentric and female values-standpoints are rooted in real material conditions structured by social class" (cited by Smith 2015, Kindle loc. 3066-70, emphasis added). In both of these instances, class is prioritized as foundational, although race and gender remain integral. On this point, Smith (2015) quotes feminist Marxist, Martha Gimenez: "To argue, then, that class is fundamental is not to 'reduce' gender or racial oppression to class, but to acknowledge that the underlying basic and 'nameless' power at the root of what happens in social interactions grounded in 'intersectionality' is class power" (Kindle loc. 3242).

One might imagine a person standing at an intersection of multiple streets, roads, or pathways, each representing a different form of oppression. For instance, as the author of this paper, my standpoint reflects a number of intersecting oppressions. I grew up poor and rural, subject to the perennial Poor White Trash stigmatype (see Bates 2011). Placism and classism have been intersecting oppressions throughout my life. I am now a middle-class, middle-aged academic working at a large, open-enrollment university and living in the suburbs, so some might argue that rurality and poverty are no longer part of who I am. They would be mistaken, however, in underestimating primary socializations. Cultural anthropologist, John Hartigan Jr. (2005), points out how class is indelibly inscribed in human behaviors that cannot simply be jettisoned by economic and geographic mobility. I recognize that in the classist and anti-rural mind, this might sound like a confession of cultural and personal deficits-immorality, laziness, and ignorance stereotypically associated with rurality and poverty. But the rural poor are no more immoral, lazy,

Bates, Vincent C. 2019. Standing at the intersection of race and class in music education. Action, Criticism, and Theory for Music Education 18 (1): 117-6o. doi:10.22176/act18.1.117 
or ignorant than any other group. That being said, the intersection where I stand also includes quite a few privileges. There is no doubt in my mind that I have benefitted from being White, heterosexual, able-bodied, and male, and that, as much as I try to avoid it, my thoughts and actions include elements of racism, heterosexism, able-ism, and patriarchy.

The Black feminists discussed earlier stood at the intersection of classism, racism, and sexism ("triple jeopardy"), with class exploitation as foundational. It might be appropriate, in this instance, to imagine capitalism as the field or space within or upon which racism and sexism intersect. Of course, other intersectional theorists survey the terrain differently. George Dei (2000) defined antiracism as "an action-oriented, educational and political strategy for institutional and systemic change that addresses the issues of racism and the interlocking systems of social oppression (sexism, classism, heterosexism, ableism)" (cited by Bradley 2017, 206). Here one could imagine a complex freeway interchange or a roundabout in a large city where many pathways meet. In his recent history of racism in America, Ibram X. Kendi (2016) goes a step further relative to race, positioning racism as the field in which other oppressions converge; he suggests that it "is in the intelligent self-interest of White Americans to challenge racism, knowing they will not be free of sexism, class bias, homophobia, and ethnocentrism until Black people are free of racism" (504).

For the sake of this inquiry, I conceptualize intersectionality dynamically and critically as a field in which complex confluences of social and material forces interact. It is dynamic in that the size and importance of fields and pathways can vary according to any of a variety of perspectives, realities, histories, or political purposes. It is vital to keep all potential pathways in view, to acknowledge one's own biases and adherence to various prevailing ideologies, to interrogate imbalances within the field, and to take deliberate actions for change. It does not pit one oppression against another. Nor do oppressions morph into a single undifferentiated mass. Rather, various oppressions (and privileges) are experienced simultaneously and shape each other; like colors in a painting, each facet retains elements of nuance and distinguishability, and can be analyzed individually or in various combinations as needed, even though the full picture remains greater than the sum of its parts.

Within this framing, classism and racism blend with and complement each other in multiple ways, sharing common characteristics while also diverging in key aspects. Marxist theorists and liberation theologians (e.g. Lake and Kress 2013, 
Rieger 2017) have typically emphasized the economic or financial aspects of class and its rootedness in the material inequalities of international neoliberal capitalism, reflecting the basic reality that poor and working classes of all races have been and continue to be exploited. Pierre Bourdieu famously extended theories of financial capital to include cultural and social currencies, a concept that "meshes well ... with studies in the construction of identity" (Söderman, Burnard, and HofvanderTrulsson 2016, Kindle loc. 287). Taking multiple possible views into account, I pose class here as both an economic reality and a contributing factor in the construction of social identities. Shannon Sullivan (2014) quotes Steph Lawlor in this regardthat "the inequalities of a class society do not end with economic inequality" (7). Nonetheless, discussions of class do still tend to draw attention to the economic aspects of injustice.

Antiracists generally understand race as a social construct with material extensions. Eduardo Bonilla-Silva (2018) argues that "after race-or class or gender-is created, it produces real effects on actors racialized as 'Black' or 'White"' (8). A considerable number of these "real effects" are economic, having to do with financial realities such as employment opportunities, salaries, public education, and housing. In his discussion of intersectionality, Joerg Rieger (2017) defines racism as "prejudice plus power" and suggests that to fully understand racism, we need to look at the sources of that power, including economic sources. "Merely discussing the prejudice of the racial majority is not enough; talking about whiteness is not enough, either, as not all White people share in its benefits equally" (355). Still, in contrast to class, discussions about racism tend to center identity and culture more often than economics.

Again, to say that race and class intersect does not mean that one element of oppression can or should simply be subsumed within the other. There are some key differences or divergences. Most strikingly, the aim of Marxism has traditionally been to achieve a classless society-a complete end to economic exploitation. Antiracists, on the other hand, generally view those who advocate the corollary-a raceless society-as not really interested in overcoming racism (Bonilla-Silva 2018). Even though race is a social construct based in part on economic exploitation, the aim is not to eradicate race but to understand race in ways that are nonhierarchical and that respect and honor racial and ethnic diversity. When class is subsumed within or conflated with race, the integral critique of neoliberal capitalism can become lost to theories about culture and identity, rendering the exploitation of poor and working classes among all races less visible. By the same token,

Bates, Vincent C. 2019. Standing at the intersection of race and class in music education. Action, Criticism, and Theory for Music Education 18 (1): 117-6o. doi:10.22176/act18.1.117 
when race is subsumed within or conflated with class, the whiteness of privilege can be overlooked. In either case, conflation draws intersectionality into singleaxis thinking because, perhaps paradoxically, intersecting oppressions have not been adequately differentiated.

Sumi Cho, Kimberlé Crenshaw, and Leslie McCall (2013) note that the concept of intersectionality "exposed how single-axis thinking undermines legal thinking, disciplinary knowledge production, and struggles for social justice" (787, emphasis added). Interesectionality is a political concept in the sense that significant, widespread, and lasting change may be more readily achieved by bringing together broad coalitions. Again, relative to Bradley's previously mentioned concern, coalitions can subsume difference. But they do not have to. Critical intersectionality recognizes and retains complexity and nuance, both within and among multiple injustices, as "an analytic tool that sheds light on the complexity of people's lives within an equally complex social context" (Collins and Bilge 2016, 25). Dynamic intersectionality allows that analyses might focus momentarily on a single-axis or pose one axis as fundamental for a time, while ultimately returning to synthesis. Additionally, by focusing on complexity (both diversity and unity) within and among, intersectionality can more readily avoid subsuming one axis into another.

I will now look more closely at two ways that intersectional considerations of race and class might be able to help tease out nuances and complexities, pursuant to increased solidarity among advocates for social justice in music education. First, intersections of race and class can highlight diversity and complexity within whiteness, thereby drawing attention to the often-overlooked needs of poor Whites. Whiteness is not monolithic, but is nuanced by or intersects with class, gender, sexuality, ability, place, and more (Sullivan 2014). Nonetheless, as bell hooks (2000) points out: "Poverty in the White mind is always primarily Black. Even though the White poor are many, living in suburbs and rural areas, they remain invisible" (Kindle loc. 125-6, emphasis added). Race, in other words, when serving as a single axis, can subsume class, especially when posing racism against monolithic White privilege, thereby eliding the oppression experienced by poor Whites. "Invisible" in this case needs some qualification, because the existence of poor Whites is readily apparent; numerical data support hooks' reminder that "the White poor are many." The following table shows the percent of children in poverty within racial and ethnic groups reported in US census data as well as the actual number of children in poverty (National Center for Educational Statistics 2014).

Bates, Vincent C. 2019. Standing at the intersection of race and class in music education. Action, Criticism, and Theory for Music Education 18 (1): 117-6o. doi:10.22176/act18.1.117 


\begin{tabular}{|l|l|l|}
\hline Racial/Ethnic Group & $\begin{array}{l}\text { Percent in } \\
\text { Poverty }\end{array}$ & $\begin{array}{l}\text { Number in } \\
\text { Poverty }\end{array}$ \\
\hline Two or more races & 21.5 & 683,000 \\
\hline Some other race & 22.6 & 52,000 \\
\hline American Indian/Alaskan Native & 34.9 & 188,000 \\
\hline Pacific Islander & 27.3 & 33,000 \\
\hline Asian & 11.6 & 385,000 \\
\hline Hispanic & 31.7 & $5,559,000$ \\
\hline Black & 38.1 & $3,725,000$ \\
\hline White & 12.5 & $4,650,000$ \\
\hline
\end{tabular}

hooks' use of "invisible" could be understood as "ignored" or "marginalized." To leave class out of the analysis, or to subsume class within race as a single axis, brings with it a real-life consequence of overlooking the needs of a large oppressed and exploited group-4.6 million children. Of course, this in no way means that needs of poor White American music students are more important than or supersede the needs of poor students of color. I am suggesting a both/and proposition rather than an either/or analytical approach, recognizing that the issues are much more complex than a simple binary with White privilege on one side and racist oppression on the other. This acknowledges the possibility that White privilege can also work against poor Whites. Contemporary concepts of whiteness are steeped in elite social and cultural values and norms against which poor Whites are measured and found deficient-or deviant-rather than diverse (Hartigan 2005, Wray 2006, Sullivan 2014). An intersectional perspective is especially important in allowing or otherwise empowering music educators to explore racial and socioeconomic complexities in this way, in their own lives and in the lives of music students, as well as to extend social justice efforts to include otherwise overlooked groups and forms of oppression.

A second way that intersectionality can enhance social justice scholarship is by troubling the often-tacit assumption that focusing on race and racism naturally takes into account the needs of all poor people of color (just as it originally troubled the assumption that feminism naturally addressed the needs of all women). Again, from bell hooks (2000):

It has been difficult for Black folks to talk about class. Acknowledging class difference destabilizes the notion that racism affects us all in equal ways. It disturbs the illusion of racial solidarity among Blacks, used by those individuals with class power to ensure that their class interests will be protected even as they transcend race behind the scenes. (Kindle loc. 178) 
It is possible for people to identify as Black or Brown and still be classist (including less conscious forms of classism), viewing poor people as inferior within one's own race and beyond. It is also possible for White antiracists to hold classist views that (as I will discuss in more detail subsequently) work at odds to their antiracist aims. When critical intersectionalities involving class diversity are elided, antiracist scholars and activists risk supporting more of an illusion of social progress based primarily on the interests and experiences of middle class or wealthy people of color. Including class with race, on the other hand, increases the likelihood that the needs of poor people of color will be taken more fully into account. To this end, the story of Dorothy-a "Black, low-income, female from an innercity neighborhood [who] moved to a university in a conservative, rural area" (Hendricks and Dorothy 2018, 65)-included in the aforementioned volume edited by Brent Talbot-provides an opportunity to theorize class in music education as it intersects with race and gender. As Karin Hendricks notes, both class and race were implicated in obstacles Dorothy experienced in her transition to a university music program (e.g. a lack of private instruction and sub-par high school music instruction).

The critical intersectionality I am recommending here requires that theorists think carefully and analytically about a full spectrum of what is written and said about race and class. One of the selections in White Privilege: Readings on the Other Side of Racism (Rothenberg 2016) is by Paul Kivel (2016), a Jewish American who argues that we "don't need to believe or accept as true everything people of color say" (208). This scepticism, of course, has always been a basic tenet of critical theory for anyone, regardless of demographics. However, it can be a rather daunting prospect for those of us who are White and, by virtue of our White privilege, inherently racist (even though overtly antiracist). How can we be confident about where White privilege and racism end and where critical thought begins, if that is even possible? On the other hand, if we just accept at face value all perspectives offered by or on behalf of people of color, then antiracism risks serving as dogma, with White contributions centering on confessions of White privilege and self-righteous judgement toward peers who have yet to confess. Some sort of generative and critical balance is needed. Perhaps this can be achieved in a critical theory based in vulnerability more than power and involving a lot more listening than criticizing. Kivel continues: "We do need to listen carefully to many voices so we understand and give credence to their experience" (208). Careful listening, after all, along with awareness of one's own White privilege, are integral to thinking

Bates, Vincent C. 2019. Standing at the intersection of race and class in music education. Action, Criticism, and Theory for Music Education 18 (1): 117-6o. doi:10.22176/act18.1.117 
critically about race. Still, Bradley (2006) insists that it is better to join the conversation, implying that we must speak rather than simply listen, and Kivel (2016) points out that we "will be ineffective as allies if we give up our ability to analyze and think critically" (208), further implying that we need to actually participate in antiracist discourse. Retreating into silence and inaction may seem a politically and professionally safe option, even in the face of positions that seem less than reasonable, but the interests of social justice are usually best served through open debate and deliberation about difficult topics.

As we direct the intersectional lens towards classed aspects of oppression, the critical and political terrain shifts somewhat. While many academics have learned to either tread with extreme caution or remain silent relative to race, we seem less guarded in how we talk about class (if we talk about it at all), particularly in regard to poor Whites. Even though stereotyping and deficit thinking relative to race have been thoroughly critiqued, it still seems politically acceptable in North America to denigrate and stereotype poor Whites (Sullivan 2014, Goad 1998). Yet the same metric used in the previous paragraph, in all fairness, ought to apply here as well: how can we be sure where class privilege and classism end and where critical thought begins? Is it even possible for those who have grown up with class privilege (economic and/or cultural) to avoid being classist? As with race, social justice relative to classed elements of intersectionality requires careful listening, vulnerability, critical discourse, and recognition of one's own biases and privilege.

In sum, a critically and dynamically intersectional approach to race and class brings with it a fertile, down-to-earth richness of complexity, the cultivation of which can yield insight and generate ongoing critical discourse, something that critical theorists have long recognized as vital to any emancipatory project (see Bates 2016b). The old adage that there are no easy answers seems apt in this case. On the one hand, Helena Liu (2018) warns that intersectionality can be used to dilute antiracism. She describes one instance on a college campus in which "discursive tactics appropriated intersectionality as a tool ... White students and staff could use to delegitimize discussions of race and racism as narrow, exclusive, or even harmful to the university's efforts to foster inclusivity" (84). Therefore, Liu continues, "ongoing theorisations of intersectionality may need to be cautious with how the concept can be used to derail the very social justice aims with which it was developed to advance" (84). On the other hand, intersectionality has the potential to subsume any of the various intersectionalities, including class, evident in the aforementioned music education literature. As bell hooks (2000) argues: "Class 
matters. Race and gender can be used as screens to deflect attention away from the harsh realities class politics exposes" (Kindle locations 171-2). We need to be cautious about how single axis antiracism-uncritically advancing monolithic whiteness as oppressive to unified blackness or brownness-can similarly undermine struggles for social justice. Universalized stories told of White privilege and racial oppression do not, nor can they, ring true for all Whites or all people of color, because each group involves other interlocking oppressions and privileges. In this light, Patricia Hill Collins and Sirma Bilge (2016) recommend intersectionality as critical praxis interrogating how power, dominance, and social inequality function in the pluriverse of everyday lives. In other words, a macro-view of "power, dominance, and social inequality" that encompasses race and class (and more) is contextualized within everyday intersections that include race and class (and more).

\section{Historical Context for Racism and Classism in America}

Intersections of class and race, as with any other social constructs, have deep historical roots. From a North American perspective, according to a considerable number of historians, wealthy and powerful people promoted and enforced the concept of race for economic purposes. Long-time Ebony Magazine editor, Lerone Bennett Jr. (1975), who passed away just this past year, made the following comments about the early American colonial population:

[They] consisted largely of a great mass of White and Black bondsmen, who occupied roughly the same economic category and were treated with equal contempt by the lords of the plantations and legislatures. Curiously unconcerned about their color, these people worked together and relaxed together. They had essentially the same interests, the same aspirations, and the same grievances. They conspired together and waged a common struggle against their common enemy - the big planter apparatus and a social system that legalized terror against Black and White bondsmen. (n.p.)

Theodore Allen's life work (2012), a two-volume history of racism in America, documents instance upon instance of Black and White cooperative defiance in the face of indentured servitude. Indentured servants were treated horribly, and minor infractions could add years to one's service; many died from poor conditions before their terms were complete and were replaced by swelling numbers of new captives. Rather than surrounded by a growing number of independent farmers, planters became seriously outnumbered by White, Black, and Indigenous forced labor. Collective resistance culminated, in the American colonies, with Bacon's Rebellion in

Bates, Vincent C. 2019. Standing at the intersection of race and class in music education. Action, Criticism, and Theory for Music Education 18 (1): 117-6o. doi:10.22176/act18.1.117 
1676, after which a relatively small group of powerful Whites passed legislation extending a degree of freedom to White laborers and inflicting lifelong slavery upon Blacks. In his introduction to a posthumous second edition of Allen's books, Jeffrey Perry (2012) describes this political strategy as follows:

The key to understanding racial oppression ... can be found in the formation of the intermediate social-control buffer stratum, which serves the interests of the ruling class. In the case of racial oppression in Virginia, any persons of discernible non-European ancestry after Bacon's Rebellion were denied a role in the social-control buffer group, the bulk of which was made up of laboring-class "whites." (Perry 2012, Kindle loc. 151-4, emphasis added)

As the "buffer class," poor Whites served two somewhat paradoxical purposes: first, as allies to White capitalists, they helped keep Black slave labor under control and, second, as Poor White Trash, they served as necessary antithesis in defining White power and privilege for Whites and Blacks alike. In his recent and awardwinning book, Stamped from the Beginning: The Definitive History of Racist Ideas in America, Kendi (2016) further explains the historical genesis of Poor White Trash.

Some-perhaps most-Blacks did look down on poor Whites. They denigrated the Whites who did not enslave them as "White trash." Actually, some uncorroborated reports suggest that enslaved Blacks created that term. Blacks had seen poor Whites doing the master's dirty work, as overseers, or on slave patrols, while clinging to the stinking fallacy that the lowest of them was still better than the highest Black person. And if poor Whites were "White trash," then what were elite Whites? Black consumers of racist ideas had come to associate Whiteness with wealth and power, and education and slaveholding. Only through the "White trash" construction could ideas of superior Whiteness be maintained, as it made invisible the majority of White people, the millions in poverty, by saying they were not ordinary Whites: they were "White trash." (238, emphasis added)

Two points in this analysis are of particular relevance here. First, as noted, the social construction of Poor White Trash is essential in constructing and upholding White privilege and White supremacy. Second, the animosity between Blacks and poor Whites came about and was perpetuated largely by design. Kendi (2016) argues that "racist ideas have not been cooked up from the boiling pot of ignorance and hate. Time and again, powerful and brilliant men and women have produced racist ideas in order to justify the racist policies of their era..." (9). He reiterates that racially discriminatory policies, motivated by "economic, political, and cultural self-interests," perpetuate racist ideas leading to ignorance and hate rather than the other way around (9). In advancing the economic, political, and cultural

Bates, Vincent C. 2019. Standing at the intersection of race and class in music education. Action, Criticism, and Theory for Music Education 18 (1): 117-6o. doi:10.22176/act18.1.117 
interests of elite Whites, these policies have negatively impacted poor Whites as well as people of color.

Although gender is not a target element in my analysis, it is worth noting how race and class are similarly nuanced when considering the capitalist exploitation of women. Beal (1969) explains:

The economic system of capitalism finds it expedient to reduce women to a state of enslavement. They oftentimes serve as a scapegoat for the evils of this system. Much in the same way that the poor White cracker of the South who is equally victimized, looks down upon Blacks and contributes to the oppression of Blacks, -So by giving to men a false feeling of superiority (at least in their own home or in their relationships with women,) the oppression of women acts as an escape valve for capitalism. Men may be cruelly exploited and subjected to all sorts of dehumanizing tactics on the part of the ruling class, but they brave someone who is below them-at least they're not women. (n.p., emphasis added)

I find Beal's concept of the "escape valve" particularly compelling as an intersectional concept: Black men can at least feel superior to Black women; poor and working-class White men, "victimized" as they are by neoliberal capitalism, can still feel superior to White women and people of color; White middle-class women can position themselves as superior to working class women, and so forth. In all instances, capitalist exploitation-a material and social force traditionally associated with class-intersects with race and gender to yield indelible social hierarchies. And this extends well beyond these three axes to include sexuality, ability, religion, geographical place, professional roles, age, and potentially much more. Nonetheless, I still maintain that it can be useful politically and epistemologically to temporarily bracket some axes in order to make a deeper analysis of others.

With this caveat, I next consider how class functions within two general forms of racism outlined by Kendi (2016), which will figure into my subsequent analysis of the events surrounding Michael Butera's resignation. First, scientific or biological racism uses scientific methods to "prove" the biological inferiority of groups according to race as defined by skin pigmentation and other physical attributes. This well-known legacy led to the eugenics movement, whereby people of color and a variety of ethnic groups were deemed genetically inferior to others. Real or imagined physical traits were identified during this time in order to argue for the biological inferiority of poor Whites as well people of color. In his extensive discussion of 19th century origins of eugenics, John Hartigan Jr. (2005) notes: "Class is as viscerally perceived and experienced as profoundly Other as are projections of

Bates, Vincent C. 2019. Standing at the intersection of race and class in music education. Action, Criticism, and Theory for Music Education 18 (1): 117-6o. doi:10.22176/act18.1.117 
racial difference" (Kindle loc. 1372-3). Both race and class, after all, are social constructs aimed at perpetuating hierarchy and inequality. Biological racism points to physical differences as justifications for oppression and inequality, while prejudice towards White groups based on physical characteristics is usually discussed in terms of classism or other oppressions. Suffice it to say that the hierarchical ordering of people biologically and "scientifically" has rationalized horrific human outcomes throughout the world ranging from segregation to ethnic cleansing and genocide. An important part of this movement, by the way, that is of special relevance to music education is the antiquated "science" of phrenology (cranial measurement), which gave us the terms "high-brow" and "low-brow" relative to elite and popular cultural practices respectively (see Janik 2014). Although it has now fallen out of favor in most circles to openly advocate biologically racist or classist stances such as these, especially in academic circles, racism and classism, as I will show, still find scientific support in ongoing debates about IQ (Saletan 2018).

Second, cultural racism maintains the inferiority of races based on environmental factors rather than genetics; supposed racial inferiority could be "overcome" through cultural assimilation. In Kendi's (2016) words, "cultural assimilationists would imagine that culturally inferior African people, placed in the proper European cultural environment, could or should adopt European culture" (20). He further describes the "uplift suasion" movement advocated by abolitionists, "based on the idea that White people could be persuaded away from their racist ideas if they saw Black people improving their behavior, uplifting themselves from their low station in American society" (123). The reference to American society is important here: it relates to the strength of American beliefs in meritocracy, the Protestant work ethic, and the American Dream (Sullivan 2014)-that in a democratic society people have only themselves to blame for their station in life. "Uplift suasion" was about changing one's culture in order to change one's social class, from poor and uneducated to middle class and enlightened, and it was believed that anyone could do it if they put forth enough effort. By this faulty logic, intergenerational poverty could be attributed to what are improperly considered deep cultural and personal deficits (Gorksi 2013).

Biological and cultural foundations to racism and classism continue today in American education. However, because discourses have (rightfully) become increasingly guarded against overt racism, the oppressive rationalities of biological and cultural hierarchy continue under the guise of concern for children living in poverty. The current discourse surrounding neuroscience is especially troubling in

Bates, Vincent C. 2019. Standing at the intersection of race and class in music education. Action, Criticism, and Theory for Music Education 18 (1): 117-6o. doi:10.22176/act18.1.117 
this regard, as poor school achievement is attributed to inferior cognitive capacities. Although the concept of IQ has deep roots in scientific racism and classism (Belkhir 1994), most current proponents of this deficit view adopt a cultural assimilationist stance, arguing that intelligence is shaped by deficits in one's physical and cultural environment (e.g. poor nutrition, lack of parental attention, less verbal interaction) and that cognitive deficits can be overcome through early and sustained intervention. In this vein, a book by Eric Jensen, Teaching with Poverty in Mind: What Being Poor Does to Kids' Brains and What Schools Can Do About It (2009, see the image below), along with a series of curriculum and professional development support materials, is promoted by ASCD, a mainstream association for educational innovation "comprising 114,000 members-superintendents, principals, teachers, and advocates from more than 127 countries...” (ASCD 2018).

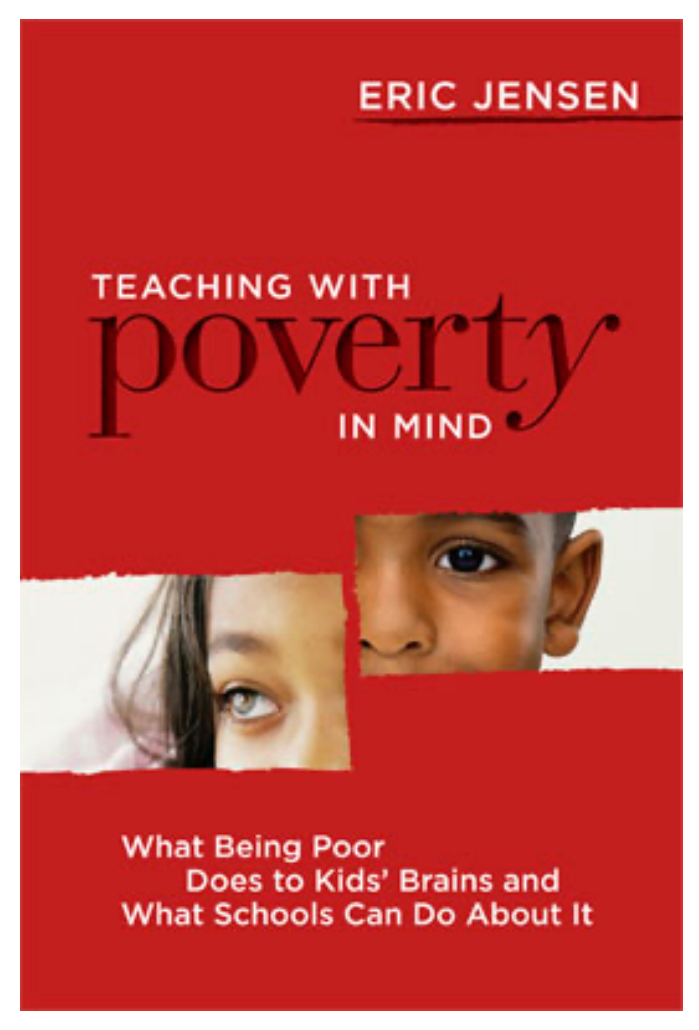

The work of Eric Jensen and others, especially in light of federal high stakes testing mandated in the No Child Left Behind legislation and the subsequent Every Student Succeeds Act, has spawned an entire industry of popular poverty resources for high poverty (typically urban) schools and school districts in the United States. Deficit perspectives bring with them an aura of truth that reinforces latent classist and racist beliefs-the reason some children do not do as well in school is simply 
because they are less intelligent or otherwise less capable. Because it is politically unacceptable anymore (understandably so) to explain inferior intelligence as genetic, the blame is placed on cultural and physical environments. Given that, as suggested earlier, White privilege often sees poverty as Black or Brown, and that classism is still an acceptable framework for overt deficit thinking even in liberal and academic settings, poverty research has become one vehicle for modern-day cultural or otherwise less noticeable racism. The following image, for example, from a popular Title I website (Fast Forword 2018), carries with it clear racial overtones-superimposing a quotation about poverty-induced brain damage over an image of a student of color:

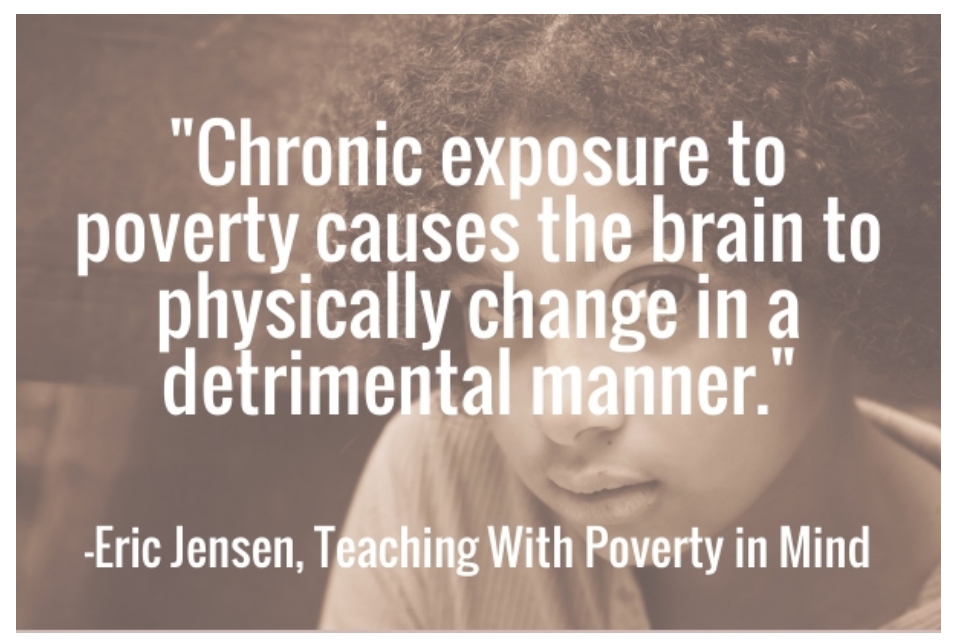

As with genetic inferiority, people still believe that cultural inferiority creates inferior bodies, although physicality has moved inward (at least overtly), implicating brain structure and cognitive capacities in the place of skin tone or other physical attributes. Instead of measuring the shape of someone's head, electromagnetic imaging is used to measure what "lights up" in the brain. Yet, as Warren Tyron (2014) argues, "modern brain imaging studies do not offer any greater explanation than phrenology did. They associate brain structures with psychological and behavioral functions, but associations are not explanations" (n.p., emphasis in the original).

The field of music education has its own history of racist and classist musical aptitude testing, also with close links to eugenics (see ground-breaking research by Hoffman 2015). Steeped in beliefs about musical talent and high culture, music educators seem to easily fall prey to cultural assimilationist views. This modern form of cultural racism and classism continues to be integral to music education, 
serving, for instance, as foundational to the popularity of El Sistema (pictured below) and other after-school programs for "at risk" youth. Bull (2016) writes:

Stigmatization of working-class people is compounded by the discourses around these programs, and by the assumption that their own culture is inadequate, and they need middle-class culture brought to them. In this way, Sistema-inspired programs, though they may be a response to living in an unequal society, may end up reinforcing the very inequality that motivates their creation by bolstering ideas about the reasons why people are poor, in particular the idea that the reason they are poor is because of their behavior and their culture. (142)

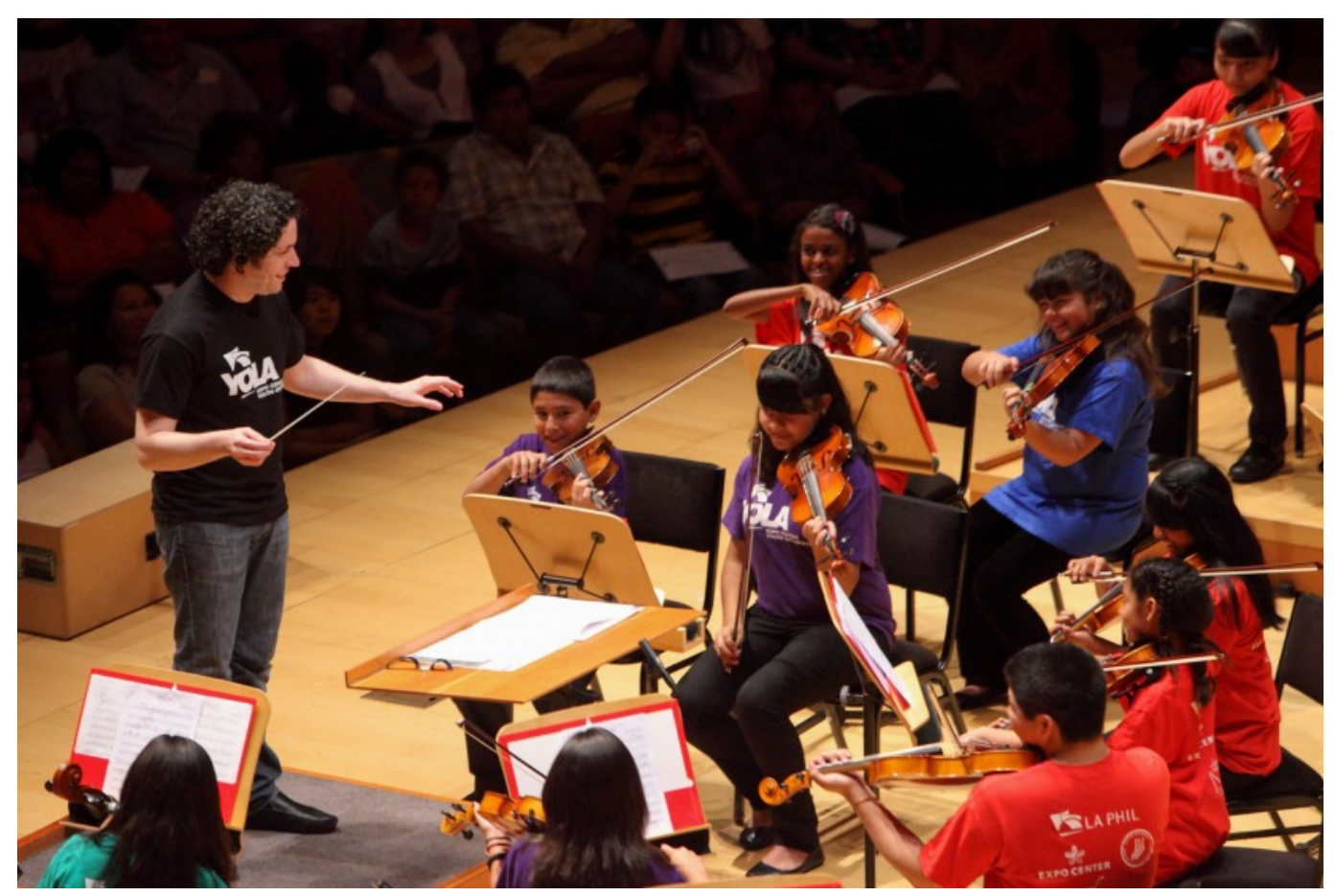

Photo by Craig T. Mathew, Mathew Imaging (Gersema 2017)

Especially considering that these programs typically serve urban schools with higher populations of students of color, and because "urban" is popularly understood as Black and Brown (Gaztambide-Fernández 2011), concern about poverty and for narrowing "achievement gaps" reflects what Eduardo Bonilla-Silva (2018) calls "blind racism," whereby "Whites rationalize minorities' contemporary status as the product of market dynamics, naturally occurring phenomena, and ... imputed cultural limitations" (2, emphasis added). The above image is from an online report from the University of Southern California promoting research conducted by its Brain and Creativity Institute, currently generating data that are used to support generous claims regarding El Sistema's potential to alleviate poverty by repairing the brains of poor children: "Music training can change both the structure

Bates, Vincent C. 2019. Standing at the intersection of race and class in music education. Action, Criticism, and Theory for Music Education 18 (1): 117-6o. doi:10.22176/act18.1.117 
of the brain's white matter, which carries signals through the brain, and gray matter, which contains most of the brain's neurons that are active in processing information" (Gersema 2017, para 2). The online report references a USC study finding enhanced musical achievement in children "of Latino ethnicity" who participated in an El Sistema program, compared "with that of children from the same underprivileged community who did not participate in any structured musical program" (Ilari et al. 2016, n.p., emphasis added). Furthermore, despite that some improvements reported in the study were not statistically significant, that the melodic task was to sing a "familiar" song ("Happy Birthday"), and that there was no improvement in rhythmic capabilities-significant limitations to say the least-the research is celebrated by USC as rather far-reaching: "Music instruction also boosts engagement of brain networks that are responsible for decision-making and the ability to focus attention and inhibit impulses" (para 2).

Such reporting is undoubtedly effective as promotional material, playing as it does into moral and intellectual stereotypes of the poor (e.g. inattentive, making bad decisions, impulsive). In addition, because the USC research focuses on a classical music performance program for Latinx children, it is rife with cultural assimilationist ideology. And because racism may masquerade as an effort to help children in poverty, it goes relatively unnoticed or taken-for-granted in a field otherwise highly sensitive to more overt forms of racism, while less cognizant of classism. What I am suggesting here is that allowing class and economics to figure more prominently at intersections such as this one might also bring racism into sharper focus.

\section{Good White People}

I would like to introduce the concept of Good White People, in an effort to shed more light on why social class receives considerably less attention than race and other social justice considerations in music education, as well as consider how White people might better work together with people of color in confronting multiple forms of oppression related to music education. As promised, I will frame this discussion within the context of controversies and events surrounding a relatively recent and possibly pivotal point in the history of the National Association for $\mathrm{Mu}$ sic Education (NAfME, formerly MENC): Michael Butera's resignation as Executive Director and CEO. On April 26, 2016, the National Endowment for the Arts convened a meeting for leaders of major arts organizations in the United States to

Bates, Vincent C. 2019. Standing at the intersection of race and class in music education. Action, Criticism, and Theory for Music Education 18 (1): 117-6o. doi:10.22176/act18.1.117 
discuss equity and diversity in the arts. Some of Butera's comments and actions at the meeting were taken as racist, the reporting of which led ultimately to his resignation. Here is how Keryl McCord (2016), a Black woman who at the time was operations director for Alternate Roots (https://alternateroots.org/about-us/), introduced the story on the Alternate Roots blog:

Mr. Butera told us that his board was all White and that he couldn't diversify his board because they aren't appointed but, rather, they are elected by the membership. Further, his membership isn't diverse because, "Blacks and Latinos lack the keyboard skills needed for this field." He also intimated that music theory is too difficult for them as an area of study. It seems that music education is on an order of magnitude of difficulty akin to medicine or law. Yet there are thousands and thousands of Black and Latino doctors and lawyers. (McCord 2016, emphasis in the original)

The outcry was swift and forceful, with the music education research and policymaking "community" calling for Butera's immediate dismissal. On social media, for instance, DeeJay Robinson, a Black music educator and academic, publicly burned his NAfME membership card (see the image below).

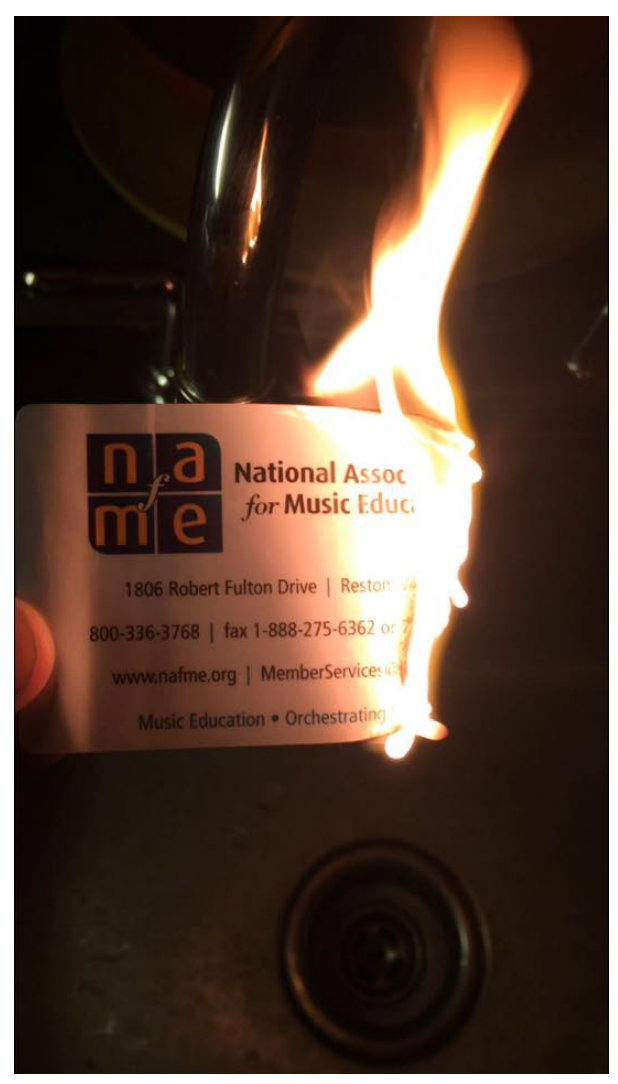

Image by Deejay Robinson

(used by permission)

Bates, Vincent C. 2019. Standing at the intersection of race and class in music education. Action, Criticism, and Theory for Music Education 18 (1): 117-60. doi:10.22176/act18.1.117 
Robinson wrote the following on his Facebook page:

Mr. Butera, I am a living example that Black people can conquer and will continue to conquer. I have 3 degrees in music. I have made it this far without you and your board. Rest assured that you will not have the last word. "I break chains all by myself, won't let my freedom rot in hell. I'm keep running cause a winner don't quit on themselves." (used by permission, emphasis added)

Robinson courageously and effectively "called out" a racist institution. Indeed, what has NAfME done to fully meet the needs of all Black and Latino students, to center anything other than elite White musical values and traditions, or to otherwise work to include all groups equitably? My own reaction was different from Robinson's, a fact that leads me once more to explore my White privilege and inherent racism. My Facebook post about the Butera incident was as follows: "Music education (NAfME) friends, this is who is representing us nationally. Are we okay with this level (any level) of racism? If this is a fair representation of what he said, Michael Butera should probably resign" (May 6, 2016). Robinson, a Black male, was outraged and acted decisively and publicly with eloquent language and a provocative act of protest. In contrast, as a White man, I approached the situation with careful deliberation and encouraged others to withhold judgement. From where he stood, Robinson's response was certainly warranted. My own standpoint reflected a racially privileged position.

This raises the question of what an appropriate response (immediate and/or long-term) might actually be from a presumptive White ally. Shannon Sullivan (2014) draws from the autobiography of Malcolm X, telling how when a young White woman once asked Malcolm X what she could do about racism, he answered, "nothing." In other words, White people are the problem and therefore cannot be the solution. Although Sullivan does encourage her fellow Whites to do everything they can to act against racism in all forms, she uses this story to critique "good White people," a designation she applies to politically liberal and progressive, middle to upper-class Whites who scapegoat Poor White Trash and White supremacists as the primary instigators in racism and White privilege. She explains that

the White desire for innocence is implicated in the middle-class dumping of responsibility for racism on lower- and working-class White people, who are posited as the true source of ongoing racial injustice. Lower-class White people allegedly are the bad White people who are too unintelligent or unenlightened to know that people of color aren't inferior to White people. With their disdain, scorn, and even hatred of lower-class White people, good White liberals often use their guilt and shame to exploit class differences among whites, which allows them to efface their own complicity in White racism and White domination. (6).

Bates, Vincent C. 2019. Standing at the intersection of race and class in music education. Action, Criticism, and Theory for Music Education 18 (1): 117-6o. doi:10.22176/act18.1.117 
Poor Whites, in other words, are caught at the intersection of race (understood primarily as culture and identity) and class (understood as socioeconomic status). Good White People maintain distance from and moral superiority over poor Whites by, among other strategies, characterizing them as irredeemably racist. In other words, classism-prejudice and differential power related to socioeconomic status-is used to deflect blame for racism. And Good White People draw from evidence and first-hand experience to support their biases. Granted, like most stereotypes or stigmas, the perception that poor and working-class Whites are overtly racist may have some basis in reality. Everyone likely knows poor Whites who say and do terribly racist things. Bonilla-Silva (2018) found in his qualitative research that, even though "all are baptized in the waters of color-blind racism," poor and working-class participants, especially older respondents "were less adept at using softer, more efficient versions of the frames and style of color-blind racism than were younger, middle-class, educated ones..." (Kindle loc. 155). However, as Robin DiAngelo (2006) notes, poor Whites are no more or less racist than wealthier Whites; "our racism is just conveyed in different ways, and we enact it from a different social location than the middle or upper classes" (52). In other words, deep social and behavioral patterns among poor and less-educated Whites-what Hartigan (2005) refers to as "etiquette"-tend to reflect less nuanced, less blind forms of racism. If racism is prejudice plus power (Rieger 2017), then the economic and cultural power of class privilege also figures into the equation. Good White People leverage evidence of overt racism, a form of racism different from their own, in order to stereotype and scapegoat poor and working-class Whites as the source of all racism. In other words, according to this conceptualization, racism emanates from the "inferior" cultures and lack of sophistication of poor Whites rather than in, for instance, the economic exploitation inflicted by late capitalism. (Incidentally, as a socially and geographically mobile academic, it could be argued that I am an aspiring Good White Person, and in some ways, I think that would be accurate; however, the circle is not complete: having grown up in rural poverty, I have not been able to scapegoat "my own people.")

By all indications, Michael Butera (pictured below with popular musician, Gladys Knight) meets Sullivan's (2014) definition of a Good White Person: middle to upper-class, concerned about racial diversity, and politically progressive and liberal, at least according to his Facebook profile and posts. This profile is also supported by what Sam Tsugawa wrote in response to my original Facebook post:

Bates, Vincent C. 2019. Standing at the intersection of race and class in music education. Action, Criticism, and Theory for Music Education 18 (1): 117-6o. doi:10.22176/act18.1.117 


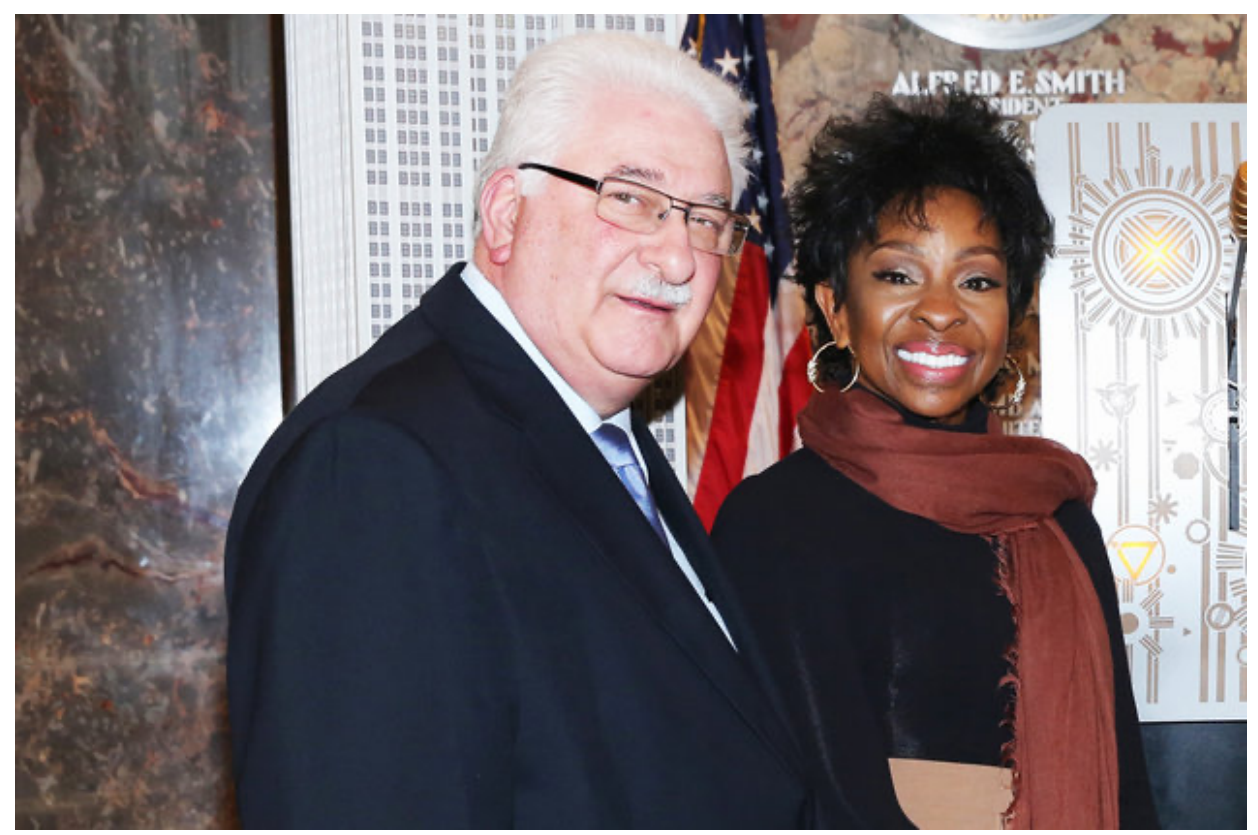

Image by Mireya Acierto/FilmMagic (Associated Press 2016)

As a newly elected member of the NAfME National Executive Board and as someone who has worked with Michael Butera as a state MEA leader, I do not believe that Mr. Butera possesses the malice that would warrant an accusation of racism... [;] as the only non-White member of the NAfME board, I am willing to give him the benefit of the doubt. Although Michael and I have disparate political views, he a liberal and I a conservative, I believe that Michael is committed to his principles, which includes the need for increased diversity in the profession. (used by permission, emphasis added)

Despite the countervailing context, Butera was condemned by White academics for an "old-fashioned” (Bonilla-Silva 2018), overt, biological form of racism. This is readily apparent in a letter to NAfME from its own Social Sciences SRIG (Special Research Interest Group) containing the following: "Despite the fact that persons of color are, indeed, underrepresented among the ranks of NAfME members and leaders, the assertion that those from different races do not possess equal musical ability is inaccurate, extremely offensive, and counter to the values we as music teachers and music teacher educators hold most dear" (emphasis added). In other words, the accusation was that Butera believed that Blacks and Latinos are inherently (biologically) less capable of learning to play the piano or master music theory-a nonsensical position, easily countered by McCord simply by listing some wonderful pianists of color. The problem with this framing is that, as Bonilla-Silva's research (2018) suggests, middle class professional people such as 
Butera generally consider this type of biological racism repugnant-more characteristic of White supremacists and Poor White Trash.

To be clear, my aim is not to defend Butera; NAfME has a long history with racism, classism, sexism, and more, and as CEO and Executive Director Butera had a responsibility to lead in addressing injustice. (And, in fact, I generally feel a degree of animosity toward all bourgeois Whites.) If Butera felt he was being misrepresented, he should have stayed in the setting and worked towards mutual understanding and actionable solutions. I would simply like to point out that reactions by White academics characterizing Butera of biological racism served to create distance between him and themselves, buffering them from deeper antiracist considerations, which parallels the tendency of Good White People to scapegoat Poor White Trash and White supremacists for all things racist. Further, I believe that more nuanced and deliberative responses from White critics might have had more comprehensive and enduring impacts in addressing institutional injustices, including racism. By more nuanced I refer especially to full recognition of blind, cultural, and systemic racism, as well as its economic aspects. As it stands, the subsequent NAfME research conference, which seemed to be aimed in part at addressing the Butera incident, included four prominent and well-attended "diversity and inclusion" panels on topics such as multiculturalism, culturally responsive teaching, "safe spaces," and access. (An exception to a general lack of criticality was a tenminute talk by Juliet Hess, 2018c, who rightfully questioned "diversity, inclusion, and access as goals, as they result in additive approaches to change rather than meaningful shifts from the ground up.")

I will explore two possibilities for a deeper and more far-reaching analysis that could have been undertaken relative to the Butera incident but were not. Focusing on accusations of biological racism, in fact, precluded meaningful discussions of potential cultural racism, which is still ubiquitous throughout the United States and beyond and, in this case, combines a judgement that Blacks and Latinos are culturally deficient due to inferior music education and related opportunities, with a belief that Blacks and Latinos ought to assimilate to the dominant Euro-centric cultural norms advanced in university schools of music and supported by NAfME. In fact, those who adhere to this reasoning are generally concerned about such deficiencies and strive to "help" poor people of color assimilate, taking for granted the superior cultural goodness of "high-brow" or otherwise elite musics. This perspective can be rather subtle. For instance, in an article entitled Missing Faces 
from the Orchestra: An Issue of Social Justice? (2012) appearing in NAfME's Music Educators Journal, Lisa DeLorenzo asserts that "poor Black and Latino children do not stand much of a chance when it comes to the experiences needed for a college music program or professional career in music" (41-2). Even though DeLorenzo suggests simply that students of color ought to have the opportunity to choose a career in classical music if they want, any interest in funneling "poor Black and Latino" children into college music programs and from there into professional orchestras or opera companies tends to promote cultural assimilation, particularly when combined with the fact that music education throughout North America still centers classical music (despite the dearth of jobs in classical music). According to this framework, racism and classism in American music education can be observed on two levels: in the lack of preparation that "poor Black and Latino children" receive, and in the fact that the university programs, for which they are being prepared, focus on elite White musical values and practices. Improved preparation and access may be steps in the right direction, but only if NAfME and other music education associations are willing to fully acknowledge, relinquish, and actively work to eradicate cultural imperialism-efforts that would necessarily have to go much deeper than celebrating diversity.

Second, Sullivan (2014) suggests that White antiracists need to do more than mimic Black or Brown antiracism, and focus more attention on addressing issues within whiteness-the diverse and intersectional experiences, prejudices, and oppressions that exist between and among Whites. This requires embracing social class as an important intersection with race in understanding and countering oppression and exploitation. As it stands, the overtly classed aspects of the controversy were all but ignored, despite clear references. After Butera resigned, NAfME selected Michael Blakeslee as the new Executive Director and CEO. Blakeslee, now in the role of NAfME apologist, suggested that Butera had actually meant to shed light on an economic problem. "Blakeslee said that many people see piano or keyboard ability as an important foundation for music educators to master. If private piano lessons are more readily available to rich, White kids than poor blacks and Latinos, then that becomes an obstacle to recruiting blacks and Latinos into music education" (Associated Press 2016). This statement, of course, glosses over the intersectionality of class and race by equating wealth with White kids and poverty with students of color. The fact is that poor and working-class students of all races are marginalized by common music education practices. Private music lessons, pi-

Bates, Vincent C. 2019. Standing at the intersection of race and class in music education. Action, Criticism, and Theory for Music Education 18 (1): 117-6o. doi:10.22176/act18.1.117 
ano lessons in particular, have a huge impact on student success in American public school and university music programs. In fact, I would venture that no other subject in North American schools relies so heavily on private instruction. In Unequal Childhoods: Class, Race, and Family Life (2011), Annette Lareau writes: "the lives of affluent and Middle-class White and Black children in my study did exhibit some key differences; yet the biggest gaps were not within social classes but, as I show, across them" (4). Middle class White and Black parents alike were kept busy after work shuttling their kids to and from private music lessons (piano lessons in particular) as well as other extra-curricular activities, while lower income children, Black as well as White, spent more time with friends and family in less formal or otherwise undirected activities while their parents were often working at an evening job. Actionable steps for NAfME and American music education could include de-centering keyboard proficiencies or other pre-requisites related to formal private instruction, as well as centering musical traditions less dependent upon private instruction-traditions that reflect and fully embrace the musical values and traditions of poor and working-class students of all races and ethnicities. This could also involve breaking down NAfME-sanctioned competitive structures, such as all-state ensembles, that further privilege the economically privileged.

As noted, McCord effectively countered any biological racism by noting the number of accomplished pianists of color. She also pointed out that "there are thousands and thousands of Black and Latino doctors and lawyers." She was correct on both counts. It should go without saying that people of color are just as capable as White people when it comes to any form of musical understanding, expression, or virtuosity. Good White People, however, by accepting and perpetuating accusations of biological racism, missed an opportunity to follow up on a key related problem, that Black and Latinx populations are seriously underrepresented among teachers and even more so among doctors and lawyers, as the following table indicates (see Johnson 2015, Elpus 2015).

\begin{tabular}{|l|l|l|}
\hline & $\begin{array}{l}\text { Black (14\% of the US } \\
\text { population) }\end{array}$ & $\begin{array}{l}\text { Latinx (18\% of the US } \\
\text { population) }\end{array}$ \\
\hline Music Teachers & $7 \%$ & $\mathbf{2 \%}$ \\
\hline Teachers & $7 \%$ & $9 \%$ \\
\hline Medical Doctors & $4 \%$ & $5 \%$ \\
\hline Lawyers & $5 \%$ & $5 \%$ \\
\hline
\end{tabular}

Bates, Vincent C. 2019. Standing at the intersection of race and class in music education. Action, Criticism, and Theory for Music Education 18 (1): 117-6o. doi:10.22176/act18.1.117 
Despite being fully capable of excelling in any of these fields, neither racial group approaches full representation. There can be no doubt that racism, understood as overt or blind prejudice, has an impact. Cultural differences may also discourage people of color and poor Whites from choosing to become music teachers; why support a culturally exclusive and elite White institution? Basic economics, however, also explain a lot. According to the National Center for Educational Statistics, only $14 \%$ of low SES people complete bachelors or higher degrees, compared to 29\% for middle SES and 60\% high SES. In America, higher education, especially graduate school, simply takes a lot of money, thereby limiting how many poor people can gain access. Higher rates of poverty among Black and Latinx populations are reflected in lower percentages earning the bachelor's degrees or, in some states, the master's degrees required to become a teacher, and even lower percentages gain entry into jobs in higher education that, in music education, require doctoral degrees.

I have attempted in the foregoing to demonstrate how the intersectionality of race and class can provide a helpful analytical frame for examining the cultural, institutional, and economic nuances and complexities of each. While I believe that the work of antiracist scholars in music education runs much deeper than that of Good White People, I also see the possibility of latent classism deterring antiracist scholars in music education from fully considering class or including class as intersectional rather than subsumed within race-a strategy (whether conscious or not) that allows one to carefully avoid taking up the cause of poor and working class Whites, the perennial scapegoats in racism. I will give just two brief examples.

First, Juliet Hess (2017) writes: "In many ways, 'traditional' music education reinscribes hierarchical relations of class and race and supports the pervasive, dominant ideology of White supremacy" (21, emphasis added). The traditional, dominant, White practices that Hess identifies include Western classical music, large ensembles, and a focus on staff notation-the standard curriculum in American music education. Hess recommends instead that we foster "skills typically associated with Black musics such as improvisation, oral tradition, and movement" (21). Although Hess mentions class along with race at the outset, her subsequent analysis focuses on Black people. Within this conceptual framework, White values are reflected in classical music traditions as opposed to Black musical practices. Critical intersectionality relative to class and race, on the other hand, recognizes that classical music reflects elite White Euro-centric (and patriarchal) cultural val- 
ues. It is not, nor has it ever been the music of poor Whites, whose old time, country, and heavy metal musics-each one associated with improvisation, oral tradition, and movement-are complex mixtures of "folk" or "low-brow" musical traditions from Europe, Africa, and America.

A second instance can be found in Bradley's 2006 ACT article. She rightly critiques as racist the following vision statement, at the time endorsed by the College Music Society:

American culture is experiencing a cycle of aesthetic poverty. This condition is marked by society's (1) seemingly universal desire for the most immediate and primal forms of artistic expression and communication at the exclusion of the deeper and more meaningful forms; (2) serious deterioration in the expectation of quality and decency in culture; and (3) the contribution of the symptoms of this cycle to the sources of some of our society's greatest problems (crime, homelessness, depression, etc.) (Harding, 2005, as cited in and with italics added by Bradley 2006).

Bradley writes that "terminology such as 'aesthetic poverty' and 'primal forms of artistic expression' ... imply a musical hierarchy based upon racialized and racist assumptions about practices of music in today's world" (10). In my experience at least, college music programs are more likely to embrace African American musi$\mathrm{cal} /$ cultural values than those associated with poor rural Whites. For instance, it is much more common that universities offer jazz studies than bluegrass, country, or heavy metal. Furthermore, as Bradley points out, "primal forms of artistic expression" does sound racially charged. But it could also refer to the musical practices of poor, rural, or working-class Whites, which also have historically been considered primitive (Bates 2013). At the very least, "aesthetic poverty" would surely implicate the musical values of poor Whites as much as those of anyone else.

In all fairness, latent racism may be at play in critical class theory in music education, where race clearly intersects but is likewise subsumed. Note the similarities between the two preceding examples of antiracism in music education and what I wrote in the following quote from Music Educators Journal article on social class (Bates 2012).

Social class also has a cultural dimension wherein beliefs, customs, and values shared by the low-income and working classes have less currency, power, or authority than do those of the middle and upper classes.... American school music has included an effort to "rehabilitate" the musical tastes of those perceived as poor-to supplant "low" culture with "high" culture. This effort is evident in American high schools when emphasis is placed on large ensembles (concert bands, orchestras, and choirs) patterned after Western art music traditions or in

Bates, Vincent C. 2019. Standing at the intersection of race and class in music education. Action, Criticism, and Theory for Music Education 18 (1): 117-6o. doi:10.22176/act18.1.117 
general music classes when priority is given to listening to and learning to appreciate orchestral "masterworks."

This statement applies equally well to poor Whites as it does for poor people of color, but the important intersectionality of race with class goes unrecognized (until now). This can be problematic conceptually as well as politically. As I will discuss in the final section, intersectional analyses have the potential to unite disparate groups under the common banner of social justice in music education.

\section{Solidarity}

Black Jeopardy, one of the most successful sketches recently on Saturday Night Live (SNL), portrays contestants trying to answer questions reflecting poor or working-class Black insider knowledge. One episode, which aired on October 22, 2016, involves Tom Hanks as a stereotypical poor White southerner, "Doug," complete with goatee and Make America Great Again hat. To everyone's surprise, Doug correctly answers every question he attempts, accumulating the most points and prompting the host to say, "Doug, you all right" and for the other contestants to chant "Go Doug, Go Doug!"-that is, until Final Jeopardy where the topic is Lives that Matter, at which point the host says, "Well it was good while it lasted, Doug." Doug says, "I've got a lot to say about this," to which the host replies, "Yeah, I'm sure you do." (My summary, of course, cannot do justice to this well-crafted sketch.)

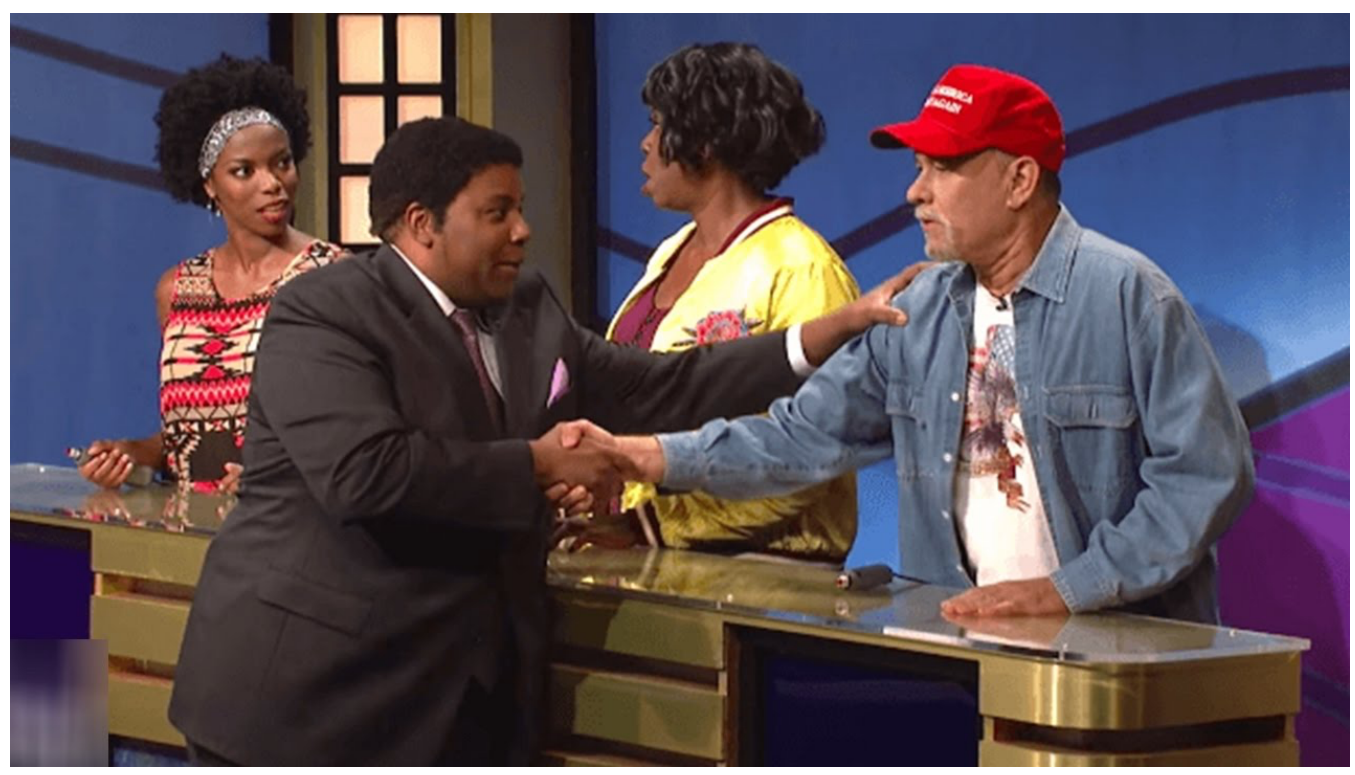

Bates, Vincent C. 2019. Standing at the intersection of race and class in music education. Action, Criticism, and Theory for Music Education 18 (1): 117-6o. doi:10.22176/act18.1.117 
So far (as of February 2019), the video has nearly 40 million views and is the second most viewed SNL YouTube video after just one year, slightly behind the most viewed that has been online for five years. Rolling Stone ranked this particular episode of Black Jeopardy one of the 10 best SNL sketches of all time (Fear 2017), Slate's Jamelle Bouie (2016) called it one of SNL's "sharpest political sketches in recent memory," and similar assessments appeared in the The Washington Post (Zak 2016) and The Atlantic (Kornhaber 2016). The 287,00o likes for the YouTube video far outweigh 11,00o dislikes. There is clearly something about this sketch that resonates with millions of people, addressing something that so many already feel intuitively. To illustrate this, I include one thread of comments that accompanied the video on YouTube, placing key points in italics to show a line of collective reasoning eventually identifying the centrality of class-that the comparison is between poor Whites and poor Blacks.

Shaya Bekele: Whoever wrote this sketch is a genius. They really highlighted some of the socioeconomic similarities between Black and White folks in this country. For better and for worse.

John Smith: Yes, even the categories sounded natural with a redneck accent (mmm, I don't know) and every cringe worthy moment from Doug ("you people") was greeted by an equally cringey moment from Darnell ("you're alright" with the subtext of 'for a White guy'). This was a beautifully orchestrated sketch down to the last detail.

Dale Ritter: This is actually good comedy coming from SNL that I don't see much of anymore. This is comedy that can be used to highlight the similarities in groups and bring them together, as opposed to the more usual mocking another group for their differences that is slung both ways.

Mufasa's Brother: Correction similarities between Black and poor White folks M Loftin: Point taken.

Mufasa's Brother: Correction similarities between poor Black folk and poor White folk

The sketch was co-written by Michael Che, who talked about it with late night talk show host Seth Myers (https://www.youtube.com/watch?v=6XaookspRsE). While Myers' questions and comments interpreted the sketch as simply portraying similarities between "Trump voters" and Blacks, Che's comments were more in line with the comments on the YouTube discussion thread: "I grew up in Manhattan in the projects, and I feel like I have a lot more in common with Southern 
Whites than I do with upper west side Whites in Manhattan.” When Che mentions upper west side Whites in Manhattan in the interview, his body language and vocal inflection portray an elite condescending pretentiousness commonly attributed to "snooty" Whites. Che clearly intended to highlight an affinity, a sense of common cause, between poor Whites and poor Blacks.

Positive interactions between Blacks and poor Whites hark back to the history of racial division in America, explored in a previous section. These instances of affinity in the SNL sketch and subsequent commentary have continued in American society since that time. For instance, at the height of the Civil Rights era, in addition to the Poor People's Campaign, a group of rural Southern Whites who had migrated to Chicago's Uptown area dubbed themselves the Young Patriots of Chicago and joined with the Black Panthers and a Puerto Rican group, the Young Lords Organization, to form the original Rainbow Coalition. "Despite its legacy of slavery, political repression, and White supremacy, the American South also had a tradition of multiracial resistance that had never been stamped out. This spirit of rebellion was reborn in Uptown against the economic deprivation and political repression in 1960's Chicago" (The Young Patriots \& The Original Rainbow Coalition n.d.; see also McCanne 2017, Sonnie and Tracy 2011).

While the poor across races recognize their class similarities and common cause, the middle class tend to downplay it (Sullivan 2011); the most privileged and powerful find it outright threatening, and their perennial strategy is to divide the poor and working classes along racial lines. Reverend Barber identifies this strategy as integral in maintaining American racial divisiveness. "The trick is when White politicians persuade poor White working-class people that the source of their pain is people of color, immigrants, and other scapegoats" (Blake 2018).

This trick, as I have suggested, is reinforced when people conceptually group all Whites together as equally privileged by their whiteness, ignoring culturally and otherwise classed nuances, and then "add insult to injury" by scapegoating poor Whites as the source for racism, homophobia, sexism, hate, and ignorance (Sullivan 2011). In a recent article in the oldest continuously published weekly in America, The Nation-a progressive magazine, by the wayJesse Myerson notes: "Pathologizing the White working class as inherently bigoted serves two functions: It discourages working-class organizing across racial lines, and it provides White liberals with a convenient scapegoat who, being White, can't charge racism" (Myerson 2017). They can, of course, charge classism, but 
classism, again, has little currency in social justice scholarship unless subsumed within race.

The trick can be thwarted by finding ways to unite poor and working classes to confront racism and classism together, along with an array of other oppressions. The following is a quote from Peggy Terry, a speaker at the Poor People's Convention in Washington, D.C., on June 19, 1968.

Poor whites are here today ... to make ourselves visible to a society whose continued existence depends on the denial of our existence. We are here today united with other races of poor people, Puerto Ricans, Mexican-Americans, Indians, and Black people in a common cause. That common cause is freedom! (cited in Sonnie and Tracy 2011)

The sentiment persists today-race joined with class (and more) in common cause. Last year bell hooks visited Utah Valley University, located in one of the whitest counties in the country. One of the attendees at hooks' lecture asked her about intersectionality. She suggested that we ought to address multiple forms of oppression simultaneously or, in her own words, "we should examine imperialist, White supremacist, capitalist patriarchy." This is similar to what Reverend Barber said at a rally this past year.

We know in America there can be no transformation in our society if you don't deal with systemic racism and systemic poverty together. In fact, Dr. King said three things: militarism, poverty, and racism. We say today there are five interlocking injustices: systemic racism, systemic poverty, ecological devastation, the war economy and militarism, and the false moral narrative of religious nationalism... (https://www.youtube.com/watch?v=EykLG2u8G3k)

Finally, Kendi (2017) recommends solidarity, as an expression of self-interest rather than altruism. He maintains that it serves the self-interest of people who wish to overcome any form of bigotry to join in the struggle against any and all other forms of bigotry. "Supporting these prevailing bigotries," he writes, "is only in the intelligent self-interest of a tiny group of super rich, Protestant, heterosexual, non-immigrant, White, Anglo-Saxon males. Those are the only people who need to be altruistic in order to be antiracist" (504). This final sentence is a rhetorical device; those in power are not going to become altruistic, to give up their wealth or power willingly. It is incumbent upon the rest of us who have made it our mission to critique privilege, power, exploitation, and oppression in and through 
our professed field of music education, to band together in solidarity. In this paper, I have looked primarily at just one intersection, race and class, and I have attempted from my own limited perspective to say something of value. There are other intersections-class with gender, gender with race, race with ethnicity, ethnicity with place, place with religion, religion with sexuality, sexuality with disability, and so many more-each facet intersecting every other facet. We are not all the same, even when we look similar. But there is enough here to unite us in a common cause-action for change in music education.

For your cause in my cause and my cause is your cause.

The more we get together, the happier we'll be. ${ }^{1}$

\section{About the Author}

Vincent Bates has earned degrees from Brigham Young University and the University of Arizona. He currently serves in the teacher education department at Weber State University. Previously, he taught horn and general music at Northwest Missouri State University and K-12 music in Eureka, Utah. He is managing editor for Action, Criticism, and Theory in Music Education and is developing an arts integration website: elementaryartsintegration.com.

\section{References}

Abramo, Joseph Michael. 2017. The phantasmagoria of competition in school ensembles. Philosophy of Music Education Review 25 (2): 150-70.

Albert, Daniel J. 2006. Socioeconomic status and instrumental music: What has research suggested about the relationship and its implications? Update: Applications of Research in Music Education, 25 (1): 39-45.

Antmann, Michael D. 2015. Socioeconomic status, instrumental music participation, and middle school student achievement. Dissertation.

Allen, Theodore W. 2012. The invention of the White race. Volumes 1 and 2. Second edition. London and New York: Verso Books. Kindle Edition.

ASCD. 2018. About ASCD. http://www.ascd.org/about-ascd.aspx

Associated Press. 2016. Music education CEO says minorities lack "keyboard skills," loses job. https://www.billboard.com/articles/business/7370409/michael-butera-music-education-advocacy-fired 
Baker, Geoffrey. 2016. Editorial Introduction: El Sistema in critical perspective. Action, Criticism, and Theory for Music Education 15(1): 10-32. act.maydaygroup.org/articles/Baker15_1.pdf

Bates, Vincent C. 2011. Sustainable school music for poor, White, rural students. Action, Criticism, and Theory for Music Education 10 (2): 100-127.

Bates, Vincent C. 2012. Social class and school music. Music Educators Journal, 33-37. doi: 10.1177/0027432112442944 http://mej.sagepub.com

Bates, Vincent C. 2013. Drawing from rural ideals for sustainable school music. Action, Criticism, and Theory for Music Education 12 (1): 24-46. http://act.maydaygroup.org/articles/BatesB12_1.pdf

Bates, Vincent C. 2016a. Foreword: How can music educators address poverty and inequality? Action, Criticism, and Theory for Music Education 15 (1): 19. act.maydaygroup.org/articles/Bates15_1.pdf

Bates, Vincent C. 2016b. Introduction: Reaffirming critical theory for social justice in music education. Action, Criticism, and Theory for Music Education 15 (5): $1-5$.

Bates, Vincent C. 2017. Critical social class theory for music education. International Journal of Education and the Arts, 18 (7): 1-24.

Bates, Vincent C. 2018a. Faith, hope, and music education. Action, Criticism, and Theory for Music Education 17 (1): 1-21. doi:10.22176/act17.2.1

Bates, Vincent C. 2018b. Back to class: Music education and poverty. Music Educators Journal 105 (2): 72-6.

Beal, Frances M. 1969. Black women's manifesto; Double jeopardy: To be Black and female. http://www.hartford-hwp.com/archives/45a/196.html

Belkhir, Jean Ait. 1994. Race, sex, class and "intelligence": Scientific racism, sexism and classism. Race, Sex \& Class 1 (2): 53-83.

Benedict, Cathy, Patrick Schmidt, Gary Bruce, and Paul Woodford, eds. 2015. The Oxford handbook of social justice in music education. New York: Oxford University Press.

Bennett, Lerone. 1975. The road not taken. Excerpt from The Shaping of Black America. Chicago: Johnson Publishing Co., 61-82. Originally published in Ebony 25 (1970): 71-7. https://msuweb.montclair.edu/ furrg/essays/bennettroad.html

Bates, Vincent C. 2019. Standing at the intersection of race and class in music education. Action, Criticism, and Theory for Music Education 18 (1): 117-6o. doi:10.22176/act18.1.117 
Bergee, Martin J. 2006. Validation of a model of extramusical influences on solo and small-ensemble festival ratings. Journal of Research in Music Education 54 (3): $244-56$.

Blake, John. 2018. A pastor helps revive MLK's most radical campaign. CNN (February 9). https://www.cnn.com/2018/02/o9/us/poor-peoples-campaign-william-barber/index.html

Bonilla-Silva, Eduardo. 2018. Racism without racists: Color-blind racism and the persistence of racial inequality in America. Fifth edition. Rowman \& Littlefield Publishers. Kindle edition.

Bouie, Jamelle. 2016. The most astute analysis of American politics in 2016? SNL's “Black Jeopardy!” sketch. Slate (October 24). https://slate.com/newsand-politics/2016/10/snls-black-jeopardy-sketch-was-the-most-astute-analysis-of-american-politics-in-2016.html

Bradley, Deborah. 2006. Music education, multiculturalism, and anti-racism. Can we talk? Action, Criticism, and Theory for Music Education 5 (2): 1-30.

Bradley, Deborah. 2007. The sounds of silence: Talking race in music education. Action, Criticism, and Theory for Music Education 6 (4): 132-62.

Bradley, Deborah. 2015. Hidden in plain sight: Race and racism in music education. In The Oxford handbook of social justice in music education, edited by Cathy Benedict, Patrick Schmidt, Gary Bruce, and Paul Woodford, 190-203. New York: Oxford University Press.

Bradley, Deborah. 2017. Standing in the shadows of Mozart: Music education, world music, and curricular change. In College music curricula for a new century, edited by Robin D. Moore. New York: Oxford University Press. Kindle edition.

Bull, Anna. 2016. El Sistema as a bourgeois social project: Class, gender, and Victorian values. Action, Criticism, and Theory for Music Education 15 (1): 12053. act.maydaygroup.org/articles/Bull15_1.pdf

Burnard, Pamela, ed. 2016. Bourdieu and the sociology of music education. New York, NY: Routledge. Kindle edition.

Cassell, Jessica. 2017. Marxism vs. intersectionality. In Defence of Marxism. https://www.marxist.com/marxism-vs-intersectionality.htm

Cho, Sumi, Kimberlé Williams Crenshaw, and Leslie McCall. 2013. Toward a field of intersectionality studies: Theory, applications, and praxis. Signs 38 (4): $785-810$.

Bates, Vincent C. 2019. Standing at the intersection of race and class in music education. Action, Criticism, and Theory for Music Education 18 (1): 117-6o. doi:10.22176/act18.1.117 
Collins, Patricia Hill, and Sirma Bilge. 2016. Intersectionality. Cambridge, UK: Polity Press. Kindle edition.

Crenshaw, Kimberlé. 1989. Demarginalizing the intersection of race and sex: A Black feminist critique of antidiscrimination doctrine, feminist theory and antiracist politics. University of Chicago Legal Forum 1989 (1.8): 139-67. https://chicagounbound.uchicago.edu/ cgi/viewcontent.cgi? referer $=\&$ httpsredir $=1 \&$ article $=1052 \&$ context $=$ uclf

Dei, George J. Sefa, and Agnes Calliste, eds. 2000. Power, Knowledge and Antiracism Education. Halifax: Fernwood.

DiAngelo, Robin J. 2006. My class didn't trump my race: Using oppression to face privilege. Multicultural Perspectives 8 (1): 51-6.

DeLorenzo, Lisa C. 2012. Missing faces from the orchestra: An issue of social justice? Music Educators Journal 98 (4): 39-46.

DeLorenzo, Lisa C. 2016. Giving voice to democracy in music education: Diversity and social justice in the classroom (Routledge Studies in Music Education). Taylor and Francis. Kindle Edition.

Doyle, Jennifer Lee. 2014. Cultural relevance in urban music education: A synthesis of the literature. Update: Applications of Research in Music Education 32 (2): 44-51.

Dyndahl, Petter, Sidsel Karlsen, Odd Skårberg, and Siw Graabræk Nielsen. 2014. Cultural omnivorousness and musical gentrification: An outline of a sociological framework and its applications for music education research. Action, Criticism, and Theory for Music Education 13 (1): 40-69. act.maydaygroup.org

Elpus, Kenneth. 2015. Music teacher licensure candidates in the United States: A demographic profile and analysis of licensure examination scores. Journal of Research in Music Education 63 (3): 314-35.

Elpus, Kenneth, and Carlos R. Abril. 2011. High school music ensemble students in the United States: A demographic profile. Journal of Research in Music Education, 59 (2): 128-45.

Fast Forword by Scientic Learning. 2018. Poverty resources. https://www.scilearn.com/k-12-schools/poverty/resources

Fear, David. 2017. 10 best 'SNL' sketches, season 42: From Trump to David S. Pumpkins. Rolling Stone. https://www.rollingstone.com/tv/tv-lists/10-best-

Bates, Vincent C. 2019. Standing at the intersection of race and class in music education. Action, Criticism, and Theory for Music Education 18 (1): 117-6o. doi:10.22176/act18.1.117 
snl-sketches-season-42-from-trump-to-david-s-pumpkins-129617/Blackjeopardy-featuring-tom-hanks-129632/

Fitzpatrick, Kate R. 2006. The effect of instrumental music participation and socioeconomic status on Ohio fourth-, sixth-, and ninth-grade proficiency test performance. Journal of Research in Music Education 54 (1): 73-84.

Gaztambide-Fernández, Rubén A. 2011. Musicking in the city: Reconceptualizing urban music education as cultural practice. Action, Criticism, and Theory for Music Education 10(1): 15-46. http://act.maydaygroup.org/articles/Gaztambide-Fernández 10_1.pdf

Gaztambide-Fernández, Rubén, and Leslie Stewart Rose. 2015. Social justice and urban music education. In The Oxford handbook of social justice in music education, edited by Cathy Benedict, Patrick Schmidt, Gary Bruce, and Paul Woodford, 456-72. New York: Oxford University Press.

Gersema, Emily. 2017. Music training can change children's brain structure and boost decision-making network. USC News. https://news.usc.edu/131274/music-training-can-change-childrens-brainstructure-and-boost-decision-making-network/

Giridharadas, Anand. 2018. Winners take all: The elite charade of changing the world. Knopf. Kindle edition.

Goad, Jim. 1998. The redneck manifesto: How hillbillies, hicks, and White trash became America's scapegoats. Simon \& Schuster.

Gorski, Paul C. 2013. Reaching and teaching students in poverty: Strategies for erasing the opportunity gap. New York: Teachers College, Columbia University.

Hall, Clare. 2018. Masculinity, class, and music education: Boys performing middle-class masculinities through music. Palgrave Macmillan UK.

Hartigan, John Jr. 2005. Odd tribes: Toward a cultural analysis of White people. Durham and London: Duke University Press. Kindle edition.

Hendricks, Karin S., and Dorothy. 2018. Negotiating communities of practice in music education. Dorothy's narrative. In Marginalized voices in music education, edited by Brent C. Talbot, 65-79. New York: Routledge. Kindle edition.

Hess, Juliet. 2013. Radical musicking: Challenging dominant paradigms in elementary music education. PhD dissertation, University of Toronto.

Bates, Vincent C. 2019. Standing at the intersection of race and class in music education. Action, Criticism, and Theory for Music Education 18 (1): 117-6o. doi:10.22176/act18.1.117 
Hess, Juliet. 2014. Troubling whiteness: Navigating White subjectivity in music education. International Society for Music Education (ISME) 2014, Porto Alegre, Brazil, July 20-25, 2014.

Hess, Juliet. 2015a. Decolonizing music education: Moving beyond tokenism. International Journal of Music Education 33 (3): 336-47.

Hess, Juliet. 2015b. Upping the "anti-": The value of an anti-racist theoretical framework in music education. Action, Criticism, and Theory for Music Education 14 (1): 66-92.

Hess, Juliet. 2016. Interrupting the symphony: Unpacking the importance placed on classical concert experiences. Music Education Research 18 (3): 1-11. doi: $10.1080 / 14613808.2016 .1202224$

Hess, Juliet. 2017. Equity and music education: Euphemisms, terminal naivety, and whiteness. Action, Criticism, and Theory for Music Education 16 (3): 15-47. doi:10.22176/act16.3.15

Hess, Juliet. 2018a. Troubling whiteness: Music education and the "messiness" of equity work. International Journal of Music Education 36 (2): 128-44. doi:10.1177/0255761417703781

Hess, Juliet. 2018b. Detroit youth speak back: Rewriting deficit perspectives through songwriting. Bulletin of the Council for Research in Music Education 216: 7-30.

Hess, Juliet. 2018c. Problematizing "diversity," "inclusion," and "access" in music education. Presentation at the 2018 NAfME Music Research and Teacher Education Conference, March 22-24, Atlanta, Georgia. Also read on Youtube (April 3, 2018). https://www.youtube.com/watch?v=9ytxe9YTyR8

Hoffman, Adria R. 2013. Compelling questions about music, education, and socioeconomic status, Music Educators Journal 100 (1).

Hoffman, Adria R. 2015. "Blessed": Musical talent, smartness, and figured identities. Equity and Excellence in Education 48 (4): 606-20.

hooks, bell. 2000. Where we stand: Class matters. Taylor and Francis. Kindle edition.

Ilari, Beatriz S., Patrick Keller, Hanna Damasio, and Assal Habibi. 2016. The development of musical skills of underprivileged children over the course of 1 year: A study in the context of an El Sistema-inspired program. Frontiers in Psychology 7: 62. doi:10.3389/fpsyg.2016.00062

Bates, Vincent C. 2019. Standing at the intersection of race and class in music education. Action, Criticism, and Theory for Music Education 18 (1): 117-6o. doi:10.22176/act18.1.117 
Institute for Policy Studies. 2018. The souls of poor folk. https://ips-dc.org/wpcontent/uploads/2018/04/PPC-Audit-Full-410835a.pdf

Janik, Erika. 2014. The shape of your head and the shape of your mind. The Atlantic (January 6). https://www.theatlantic.com/health/archive/2014/o1/the-shape-of-your-head-and-the-shape-of-yourmind/282578/

Jensen, Eric. 2009. Teaching with poverty in mind. What being poor does to kids' brains and what schools can do about it. Alexandria, Virginia: ASCD.

Johnson, Steven Ross. 2015. Black and Hispanic doctors still underrepresented in the U.S. Modern Healthcare (August 24). http://www.modernhealthcare.com/article/20150824/NEWS/150829945

Kelly-McHale, Jacqueline, and Carlos R. Abril. 2015. The space between worlds: Music education and Latino children. In The Oxford handbook of social justice in music education, edited by Cathy Benedict, Patrick Schmidt, Gary Bruce, and Paul Woodford, 156-72. New York: Oxford University Press.

Kendi, Ibram X. 2016. Stamped from the beginning: The definitive history of racist ideas in America. PublicAffairs. Kindle Edition.

Kivel, Paul. 2016. How White people can serve as allies to people of color in the struggle to end racism. In White privilege: Essential readings on the other side of racism, $5^{\text {th }}$ ed., edited by Paula S. Rothenberg, 207-13. New York: Worth Publishers. Kindle Edition.

Kornhaber, Spencer. 2016. SNL's surprisingly affectionate portrayal of a Trump supporter. The Atlantic (October 24). https://www.theatlantic.com/entertainment/archive/2016/10/Black-jeopardy-snl-tom-hanks-donald-trumpsupporter/505142/

Kraus, Michael W., Jun Won Park, and Jacinth J. X. Tan. 2017. Signs of social class: The experience of economic inequality in everyday life. Perspectives on Psychological Science 12 (3): 422-35.

Ladson-Billings, Gloria. 2015. You gotta fight the power: The place of music in social justice education. In The Oxford handbook of social justice in music education, edited by Cathy Benedict, Patrick Schmidt, Gary Bruce, and Paul Woodford, 406-20. New York: Oxford University Press.

Lareau, Annette. 2011. Unequal childhoods: Class, race, and family life. University of California Press. Kindle edition.

Bates, Vincent C. 2019. Standing at the intersection of race and class in music education. Action, Criticism, and Theory for Music Education 18 (1): 117-6o. doi:10.22176/act18.1.117 
Lake, Robert, and Tricia Kress, eds. 2013. Paulo Freire's intellectual roots: Toward historicity and praxis. New York, NY: Bloomsbury. Kindle edition.

Lind, Vicki R., and Constance L. McKoy. 2016. Culturally responsive teaching in music education: From understanding to application. New York: Routledge.

Liu, Helena. 2018. Re-radicalising intersectionality in organisation studies. Ephemera: Theory and Politics in Organization 18 (1): 81-101.

Logan, Owen. 2016. Lifting the veil: A realist critique of Sistema's upwardly mobile path. Action, Criticism, and Theory for Music Education 15 (1): 58-88. act.maydaygroup.org/articles/Logan15_1.pdf

Marsh, Kathryn. 2015. Music, social justice, and social inclusion: The role of collaborative music activities supporting young refuges and newly arrived immigrants in Australia. In The Oxford handbook of social justice in music education, edited by Cathy Benedict, Patrick Schmidt, Gary Bruce, and Paul Woodford, 173-89. New York: Oxford University Press.

Moore, Robin D., ed. 2017. College music curricula for a new century. New York: Oxford University Press. Kindle edition.

McAnally, Elizabeth Ann. 2013. General music and children living in poverty. General Music Today 26 (3): 25-31. doi: 10.1177/1048371313478611

McCall, Joyce M. 2018. Speak no evil: Talking race as an African American in music education. In Marginalized voices in music education, edited by Brent C. Talbot, 13-27. New York: Routledge. Kindle edition.

McCanne, Michael. 2017. The Panthers and the Patriots. Jacobin. https://www.jacobinmag.com/2017/05/Black-panthers-young-patriots-fredhampton

McCord, Keryl. 2016. Why we must have inclusion, diversity, and equity in the arts: A response to the National Association for Music Education. Alternate ROOTS (May 4). https://alternateroots.org/why-we-must-have-inclusion-diversity-and-equity-in-the-arts-a-response-to-the-national-association-formusic-education/

Myerson, Jesse A. 2017. Trumpism: It's coming from the suburbs: Racism, fascism, and working-class Americans. The Nation, May 8. https://www.thenation.com/article/trumpism-its-coming-from-the-suburbs/

National Center for Education Statistics. 2014. Table 102.60. Number and percentage of children under age 18 living in poverty, by family structure, race/ethnicity, and selected racial/ethnic subgroups: 2009 and 2014. Digest

Bates, Vincent C. 2019. Standing at the intersection of race and class in music education. Action, Criticism, and Theory for Music Education 18 (1): 117-6o. doi:10.22176/act18.1.117 
of Education Statistics. https://nces.ed.gov/programs/digest/d15/tables/dt15_102.60.asp

Perry, Jeffrey B. 2012. Introduction to the second edition. In The invention of the White race, 2nd ed., by Theodore W. Allen. London and New York: Verso Books. Kindle edition.

Rieger, Joerg. 2017. Empire, deep solidarity, and the future of liberation theology. Political Theology 18 (4): 354-64.

Roberts, J. Christopher, and Patricia Shehan Campbell. 2015. Multiculturalism and social justice: Complementary movements for education in and through music. In The Oxford handbook of social justice in music education, edited by Cathy Benedict, Patrick Schmidt, Gary Bruce, and Paul Woodford, 27286. New York: Oxford University Press.

Robinson, Deejay, and Karin S. Hendricks. 2018. Black keys on a White piano: A Negro narrative of double-consciousness in American music education. In Marginalized voices in music education, edited by Brent C. Talbot, 28-45. New York: Routledge. Kindle edition.

Rothenberg, Paula S. 2016. White privilege: Essential readings on the other side of racism. New York: Worth Publishers. Kindle Edition.

Saletan, William. 2018. Stop talking about race and IQ. Slate. https://slate.com/news-and-politics/2018/04/stop-talking-about-race-andiq-take-it-from-someone-who-did.html

Shevock, Daniel J. 2018. Eco-literate music pedagogy. New York: Routledge.

Shevock, Daniel J., and Vincent C. Bates. 2019. “A music educator's guide to saving the planet." Music Educators Journal (in press).

Shieh, Eric. 2015. Relationship, rescue, and culture: How El Sistema might work. In The Oxford handbook of social justice in music education, edited by Cathy Benedict, Patrick Schmidt, Gary Bruce, and Paul Woodford, 567-81. New York: Oxford University Press.

Slater, Jessica, Dana L. Strait, Erika Skoe, Samantha O'Connell, Elaine Thompson, and Nina Kraus. 2015. Longitudinal effects of group music instruction on literacy skills in low-income children. PLoS ONE 9 (11): e113383. doi:10.1371/journal.pone.0113383

Smith, Sharon. 2015. Women and socialism: Class, race, and capital. Chicago, IL: Haymarket Books. Kindle Edition.

Bates, Vincent C. 2019. Standing at the intersection of race and class in music education. Action, Criticism, and Theory for Music Education 18 (1): 117-6o. doi:10.22176/act18.1.117 
Söderman, Johan, Pamela Burnard, and Ylva Hofvander-Trulsson. 2016. Contextualising Bourdieu in the field of music and music education. In Bourdieu and the sociology of music education, edited by Pamela Burnard. New York, NY: Routledge. Kindle edition.

Sonnie, Amy, and James Tracy. 2011. Hillbilly nationalists, urban race rebels, and Black power: Community organizing in radical times. Melville House. Kindle Edition.

Soto, Amanda. 2015. New faces in old spaces: Mexican American musical expressions and music equity within the music curriculum. In The Oxford handbook of social justice in music education, edited by Cathy Benedict, Patrick Schmidt, Gary Bruce, and Paul Woodford, 631-43. New York: Oxford University Press.

Speer, Bryn. 2012. Socioeconomic status and band contest ratings. Texas Music Education Research.

Sullivan, Shannon. 2014. Good White people: The problem with middle-class White antiracism. Albany: State University of New York Press. Kindle edition.

Talbot, Brent C., ed. 2018. Marginalized voices in music education. New York: Routledge. Kindle edition.

Thornton, Darrin. 2018. Why just me (or few others) in music education. In Marginalized voices in music education, edited by Brent C. Talbot, 46-64. New York: Routledge. Kindle edition.

Tierney, Adam, Jennifer Krizman, Erika Skoe, Kathleen Johnston, and Nina Kraus. 2013. High school music classes enhance the neural processing of speech. Frontiers in Psychology. doi: 10.3389.psyg.2013.00855

Tyron, Warren W. 2014. Brain imaging as modern phrenology. Elsevier, SciTech Connect. http://scitechconnect.elsevier.com/brain-imagining-modern-phrenology/

Woodward, Sheila. 2015. Music: An alternative education in the South African freedom struggle. In The Oxford handbook of social justice in music education, edited by Cathy Benedict, Patrick Schmidt, Gary Bruce, and Paul Woodford, 614-30. New York: Oxford University Press.

Wray, Matt. 2006. Not quite White: White trash and the boundaries of whiteness. Durham and London: Duke University Press.

Bates, Vincent C. 2019. Standing at the intersection of race and class in music education. Action, Criticism, and Theory for Music Education 18 (1): 117-6o. doi:10.22176/act18.1.117 
Wright, Ruth. 2015. Music education and social reproduction: Breaking cycles of injustice. In The Oxford handbook of social justice in music education, edited by Cathy Benedict, Patrick Schmidt, Gary Bruce, and Paul Woodford, 34056. New York: Oxford University Press.

The Young Patriots \& The Original Rainbow Coalition. n.d. http://www.youngpatriots-rainbowcoalition.org/

Zak, Dan. 2016. Forget Trump and Clinton. 'Black Jeopardy' is SNL's best political sketch this year. The Washington Post (October 24). https://www.washingtonpost.com/news/arts-and-entertainment/wp/2016/10/24/forgettrump-and-clinton-Black-jeopardy-is-snls-best-political-sketch-thisyear/?utm_term=.1d87e2cd6ed8

\section{Note}

${ }^{1}$ I used to teach The More We Get Together the Happier We'll Be back when I worked as an elementary music specialist. One verse went, "for your friends are my friends and my friends are your friends." In another verse, participants sing each other's names: "There's (name) with (name) and (name) with (name)." So, these two lines along with the prose just a bit earlier are variations on this American folk song, offered in the same spirit as the original. 